\title{
Identifikasi Potensi dan Pengembangan Sistem Pertanian Organik menuju Bali Pulau Organik
}

\author{
Anak Agung Istri Kesumadewi ${ }^{1}$, I Wayan Susila ${ }^{2}$, Gusti Alit Gunadi ${ }^{3}$, \\ Dewa Gede Raka Sarjana ${ }^{4}$, I Wayan Diara ${ }^{5}$, Gusti Ngurah Alit Susanta Wirya ${ }^{6}$ \\ 1,3,5,6Program Studi Agroekoteknologi Fakultas Pertanian, Universitas Udayana \\ ${ }^{2}$ Program Studi Agribisnis Fakultas Pertanian, Universitas Udayana \\ Email: ${ }^{1}$ aai-kusumadewi@live.com, ${ }^{2}$ w1sus@yahoo.com, ${ }^{3}$ alitgunadi@unud.ac.id, \\ ${ }^{4}$ rakasarjana@unud.ac.id, ${ }^{5}$ wayandiara@unud.ac.id, ${ }^{6}$ susantawirya@unud.ac.id
}

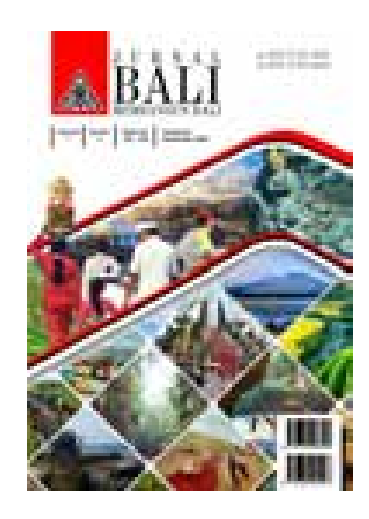

Sejarah Artikel

Diterima pada 17 Juli 2020

Direvisi pada 20 Juli 2020

Disetujui pada 12 Agustus 2020

\section{Abstrak}

Tujuan: Dengan mengadopsi sistem pertanian yang selaras alam melalui pendekatan sistem pertanian organik diharapkan menghasilkan komoditas yang sehat dan aman untuk dikonsumsi dan memiliki nilai jual yang lebih tinggi sehingga ke dua misi tersebut dalam jangka panjang dapat dicapai.

Metode Penelitian: Penelitian mengenai identifikasi potensi dan pengembangan sistem pertanian organik menuju Bali pulau organik telah dilakukan diseluruh wilayah kabupaten dan Kota di Provinsi Bali sejak bulan Mei - Desember 2019. Penelitian dilakukan melalui survei lapang dan hasilnya disepakati melalui FGD bersama para stakeholder.

Temuan: Pengembangan sistem pertanian organik potensial dilakukan hampir seluruh kabupaten di Bali kecuali di Kabupaten Klungkung dan Kota Denpasar.

Implikasi: Inovasi yang dihasilkan dari penelitian ini adalah sistem database pertanian organik Provinsi Bali yang online, terintegrasi, kompak, ringan, dan mudah dioperasikan.

Kata kunci: pertanian organik, sertifikat organik, database pertanian organik.

\section{Abstract}

Purpose: By adopting an agriculture system that is in harmony with nature through an organic farming system approach, it is expected to produce commodities that are healthy and safe for consumption and have a higher economic value so that the two missions can be achieved in the future.

Research methods: Research on identifying the potential and development of organic farming systems towards Bali organic islands had been carried out in all regencies and cities in Bali Province on May - December 2019. The research was conducted through a field survey and the results were agreed through FGD with stakeholders.

Findings: Development of organic farming systems potentially carried out in almost all districts in Bali except in Klungkung Regency and Denpasar City.

Implications: The innovation result of this research is the online, integrated, compact, lightweight, and easy to operate organic database system for Bali Province.

Keywords: organic farming, organic certificate, organic farming database.

\section{PENDAHULUAN}

Sektor pertanian memiliki peranan strategis sebagai lumbung pangan lokal dan juga kontributor penting bagi sektor pariwisata di Pulau Bali. Ironisnya, sektor pertanian justru belum mampu menyejahterakan masyarakat Bali terutama para petani dan sebagian besar pelaku agribisnis. Rendahnya daya dukung sektor pertanian terhadap perekonomian di Bali tercermin dari 
dokumentasi Badan Pusat Statistik Provinsi Bali (2019) yang menyatakan bahwa sumbangan sektor pertanian terhadap struktur ekonomi di Bali hanya sebesar 14,28 \%. Kondisi tersebut bersama-sama dengan peningkatan jumlah penduduk Bali merupakan ancaman bagi ketersediaan pangan untuk masyarakat Bali dan dalam jangka panjang berdampak terhadap kelestarian sumberdaya di Bali. Oleh karena itu, ketahanan dan kemandirian pangan serta peningkatan kesejahteraan masyarakat Bali merupakan salah satu fokus utama Pemerintah Daerah Bali sebagaimana tertuang dalam misi pertama dan kedua dari Visi "Nangun Sat Kerthi Loka Bali” melalui Pola Pembangunan Semesta Berencana menuju Bali Era Baru. Pemerintah Daerah Bali berupaya mewujudkan masyarakat yang sehat dan sejahtera melalui pembenahan sistem pertanian lokal dengan sekaligus meningkatkan kesejahteraan petani dan nilai tambah komoditas pertanian.

Dalam upaya mencapai kemandirian pangan dan meningkatkan kesejahteraan masyarakat Bali guna menyongsong Bali menuju Era Baru, maka sektor pertanian harus berbenah secara dini, komprehensif, konsisten, terarah, dan berkelanjutan. Pembenahan yang dilakukan seyogyanya bersifat holistik dengan mempertimbangkan aspek sumberdaya lahan, sumberdaya manusia, teknologi, dan potensi geografis pulau Bali sebagai etalase pariwisata nasional bagi dunia Internasional. Dengan mengadopsi sistem pertanian yang selaras alam melalui sistem pertanian organik, sektor pertanian akan menghasilkan komoditas yang sehat dan aman untuk dikonsumsi serta memiliki nilai jual yang lebih tinggi. Dengan demikian, segala upaya pembenahan sektor pertanian diarahkan untuk mengubah secara bertahap sistem pertanian yang diterapkan di Bali menjadi sistem pertanian organik guna mewujudkan Bali sebagai pulau organik. Pelaksanaan program tersebut secara politik dan teknokratik akan sejalan dengan Bali Green and Clean Program, Go Organic 2010, dan pembentukan 1000 desa organik melalui Nawacita sehingga jelas akan membawa pulau Bali sebagai salah satu produsen pangan organik di Indonesia.

Guna mendukung pelaksanaan pertanian organik, rancangan pengembangan pertanian organik nasional telah disusun bertahap sejak tahun 
2001-2010 (Sulaeman, 2006) sehingga ditatanan lokal, Bali perlu menyinergikan pengembangan sistem pertanian yang akan diimplementasikan dengan kebijakan nasional. Sejalan dengan upaya tersebut, tulisan ini disusun untuk mengulas hasil penelitian mengenai identifikasi potensi dan pengembangan sistem pertanian organik menuju Bali pulau organik. Pelaksanaan kajian ini merupakan langkah awal yang telah dilakukan oleh Pemerintah Provinsi Bali dalam mengevaluasi potensi sistem pertanian organik di Bali guna mendukung pengembangan pertanian organik untuk mewujudkan Bali sebagai pulau organik.

METODE PENELITIAN

Penelitian ini dilakukan di seluruh kabupaten dan kota di Bali sejak bulan Mei sampai dengan Desember tahun 2019. Pelaksanaan penelitian dirancang dalam 3 tahapan yang meliputi (1) Identifikasi kondisi kekinian pelaksanaan pertanian organik di Bali, (2) Potensi pengembangan pertanian organik di Bali, dan (3) Pemetaaan dan pembangunan basisdata dan Geoportal WebGIS "Pertanian Organik Provinsi Bali"

\section{Identifikasi Kondisi Kekinian Pelaksanaan Pertanian Organik di Bali}

Identifikasi kondisi kekinian pelaksanaan pertanian organik di Bali dilakukan secara deskriptif melalui studi pustaka, survei, observasi, wawancara, dan diskusi terfokus (Focus Group Discussion atau FGD). Data yang digunakan dalam penelitian ini adalah data sekunder dan data primer. Data sekunder diambil dari dokumentasi di Dinas Pertanian dan Ketahanan Pangan Propinsi Bali. Lokasi survei untuk mendapatkan sumber data primer ditentukan secara purposif berdasarkan data sekunder mengenai daerah tempat dilakukannya usahatani organik dan bentuk turunannya. Sumber data primer adalah petani atau kelompok tani pelaku usahatani pertanian organik, peternak, konsumen, penjual, dan penyedia saprotan organik. Data primer diperoleh dengan teknik wawancara berdasarkan kuisioner. Data primer yang dimaksud adalah :

1. Iokasi budidaya pertanian organik,

2. jenis, luas, produksi, produktivitas, dan waktu panen komoditas organik, 
3. potensi bahan baku pupuk dan pestisida organik dan hayati,

4. jumlah unit usaha/industri pengolahan pupuk dan pestisida organik dan hayati,

5. jumlah unit usaha perdagangan sarana produksi pertanian (saprotan) organik,

6. data profil dan tipologi usahatani pertanian organik eksisting di Bali

7. kapasitas manajerial petani dan implementasi teknologi dalam sistem pertanian organik di Bali,

8. jenis kendala utama yang dihadapi dalam penerapan sistem pertanian organik di Bali dan solusi yang dapat dikembangkan untuk mengatasi kendala tersebut,

9. jumlah unit usaha pengolahan dan pemasaran produk organik,

10. lembaga sertifikasi usaha dan produk pertanian organik,

11. jumlah kelompok tani (poktan) dan gabungan kelompok tani (gapoktan) bersertifikat organik,

12. sejarah pelaksanaan sistem pertanian organik dan sertifikasi.

Suatu komoditas dinyatakan organik apabila diproduksi melalui sistem budidaya organik sesuai dengan kriteria dalam Permentan Nomer 64 Tahun 2013 tentang Sistem Pertanian Organik dan dibuktikan dengan kepemilikan sertifikat organik (yang masih berlaku) yang diberikan oleh lembaga sertifikasi organik berkompeten yang beroperasi di Indonesia. Sistem budidaya pertanian dinyatakan telah dilakukan dengan menerapkan GAP (Good Agricultural Practices) apabila pelaku/petani mampu menunjukkan sertifikat Prima aktif yang dimiliki. Petani atau gapoktan yang memiliki sertifikat organik yang masih berlaku aktif dinyatakan sebagai petani organik bila masih menerapkan sistem budidaya organik, sedangkan mereka yang masih memiliki sertifikat Prima yang masih berlaku dan masih menerapkan prinsip GAP dinyatakan masih melakukan GAP.

Data yang diperoleh dianalisis secara deskriptif dengan pendekatan kualitatif. Hasil analisis data selanjutnya digunakan sebagai dasar mengidentifikasi minat masyarakat dalam melakukan sistem pertanian organik dan komoditas yang dipilih, kendala yang dihadapi, potensi pengembangannya, 
serta dukungan legal yang diperlukan. Guna menyatukan pandangan mengenai hasil penelitian yang diperoleh, selanjutnya dilakukan Focus Group Discussion (FGD) dengan melibatkan narasumber berikut:

1. pelaku usahatani organik,

2. wakil tenaga kerja di masing-masing usahatani organik,

3. pelaku usaha bioindustri setempat yang mendukung kegiatan usahatani organik,

4. industri lain pengguna barang dan jasa dari usahatani organik,

5. Pemda (Dinas Pertanian, Dinas Perkebunan, Deperindag, Dinas Pekerjaan Umum, Departemen Pariwisata, Kepala Desa dan Camat setempat).

\section{Potensi Pengembangan Pertanian Organik di Bali}

Potensi pengembangan pertanian organik dimasing-masing kabupaten dan kota di Bali di survei dan dianalisis berdasarkan beberapa komponen pendukung. Komponen pendukung yang didata adalah kapasitas sumberdaya manusia (SDM), dukungan sarana prasarana, ketersediaan lahan, pengakuan harga, kesesuaian teknik budidaya dengan Permentan Nomer 64 Tahun 2013, serta perolehan dan status sertifikat. Analisis kapasitas SDM dalam penelitian ini dilakukan dengan metode deskriptif kualitatif terhadap data yang diperoleh dari responden. Responden ditentukan secara purposif terhadap stakeholder dalam sistem pertanian organik. pengambilan data dilakukan dengan teknik wawancara terstruktur dan mendalam (deep structured interview) terhadap responden untuk memperoleh data dan informasi tentang umur responden, jenis kelamin responden, tingkat pendidikan responden pekerjaan utama, dan kemampuan manajerial.

Dukungan sarana dan prasarana dalam pengembangan sistem pertanian organik dikaji melalui penelitian yang dilakukan dengan metode studi pustaka, survei, observasi, dan wawancara terhadap stakeholder terkait. Responden ditentukan secara purposif yang meliputi kelian subak, petani, Dinas PU, Dinas Pertanian, Dinas Peternakan, dan Dinas Perkebunan, Dinas Perijinan, dan Departemen Perindustrian dan Perdagangan. Data primer pendukung pengembangan pertanian organik yang akan digali dari responden 
antara lain adalah jenis sarana dan prasarana, ketersediaan sarana dan prasarana, dan fungsi sarana dan prasarana. Komponen dukungan ketersediaan lahan, pengakuan harga, kesesuaian teknik budidaya dengan Permentan Nomer 64 Tahun 2013, serta perolehan dan status sertifikat direkapitulasi dari hasil survei pada penelitian tahap I. Keseluruhan data tersebut selanjutnya dianalisis secara deskriptif.

\section{Pemetaan dan Analisis Pembangunan Basisdata dan Geoportal WebGIS "Pertanian Organik Provinsi Bali"}

Penelitian ini dilakukan dengan pendekatan survei untuk mengumpulkan data primer dan sekunder. Data yang diperoleh dianalisis secara kualitatif dan kuantitatif. Data utama selanjutnya ditampilkan dalam Geoportal WebGis "Pertanian Organik Provinsi Bali". Pelaksanaan penelitian secara teknis diawali dengan penyusunan desain survei yang meliputi data yang akan dikumpulkan, pembuatan peta kerja dan form survei, lalu secara aktif ke lapangan untuk mendapatkan data yang akurat. Data primer kuantitatif dan kualitatif, dikumpulkan dari hasil survei lapangan melalui observasi, dokumentasi dan pengukuran obyek penelitian. Data sekunder bersumber dari instansi terkait di lingkungan Pemda Bali, laporan hasil penelitian atau studi yang dilakukan oleh instansi pemerintah, lembaga swasta maupun perguruan tinggi yang dapat digunakan untuk melengkapi hasil dari survei atau proses lain yang dilakukan.

Data primer yang diperlukan meliputi peta lokasi, luasan, komoditas utama, periode panen, jumlah produksi, produktivitas, distribusi saprotan, status sertifikasi, dan historis pertanian organik. Data tersebut direkap dari hasil penelitian tahap I. Data sekunder yang dikumpulkan dari dinas terkait adalah data yang dapat digunakan untuk menunjang proses pekerjaan meliputi: data citra satelit, peta-peta terdahulu, data dasar wilayah administrasi, penggunaan lahan, titik lokasi, dll, dokumen dokumen terkait.

Tahapan kegiatan yang dilakukan adalah: persiapan, survei pendahuluan, survei data primer, kompilasi data survei, penyusunan database, dan pembuatan aplikasi Geoportal WebGis "Pertanian Organik Provinsi Bali". Pada tahap awal kegiatan dilakukan penyiapan gambar citra satelit dan peta- 
peta pendukung lainnya yang memiliki koordinat bumi yang tepat. Data hasil survei didigitasi menjadi data spasial dilanjutkan dengan pengisian atribut sekaligus metadata guna menjadi sistem basis data spasial yang terpadu.

Hasil survei dikembangkan menjadi format data spasial Shapefile. Shapefile adalah format data geospasial yang umum untuk perangkat lunak sistem informasi geografis. Shapefile dikembangkan dan diatur oleh ESRI sebagai spesifikasi terbuka untuk interoperabilitas data antara ESRI dan produk perangkat lunak lainnya. Sebuah "shapefile" biasanya terdiri dari kumpulan file yang berekstensi ".shp", ".shx", ".dbf", dan ekstensi lainnya pada sebuah nama yang sama. Saat penggunaan, shapefile sebenarnya yang dipakai adalah yang berekstensi ".shp", namun file ini tidak lengkap dan membutuhkan file lainnya. Shapefile keruangan digambarkan dengan geometri: titik, garis, dan luasan. Geometri tersebut, sebagai contoh, dapat mewakili pancuran, jalan, sungai, danau dan lainnya. Tiap bagian memiliki atribut yang menjelaskan atribut tersebut, seperti nama jalan atau ketinggian tempat. Pada setiap shapefile (shp) terdapat satu file dengan format *.dbf atau file format dBASE. dBASE merupakan salah satu format yang luas digunakan oleh banyak aplikasi yang membutuhkan format sederhana untuk menyimpan data-data secara terstruktur.dBASE adalah sebuah sistem manajemen basis data relasional (RDBMS) yang secara luas digunakan pada data spasial. File shapefile dan batabase inilah yang dikembangkan menjadi bentuk basisdata pada sistem WebGIS.

Perangkat lunak aplikasi berbasis web menggunakan platform open source sehingga tidak akan ada benturan dalam masalah hak cipta/ hak pengguna. Platform WebGIS yang bersifat open source akan memudahkan dalam instalasi dan tanpa kaitan hak cipta. Fitur open source yang digunakan adalah dari OGC service provider, RDBMS, webserver hingga front-end. Setelah proses penyusunan database selesai dilakukan, maka selanjutnya dibuat aplikasi webGIS dengan tujuan untuk mempermudah pengguna dalam mencari data, serta menampilkan peta dan data multimedia yang diperoleh.

Secara jelas, pembangunan webGIS pertanian organik Provinsi Bali dibagi kedalam empat bagian, yaitu pembangunan basis data, aplikasi server, 
interface dan user/client application. Keempat bagian tersebut menggunakan aplikasi opensource. Diagram alir mengenai pembangunan aplikasi webGIS ditampilkan pada Gambar 1.

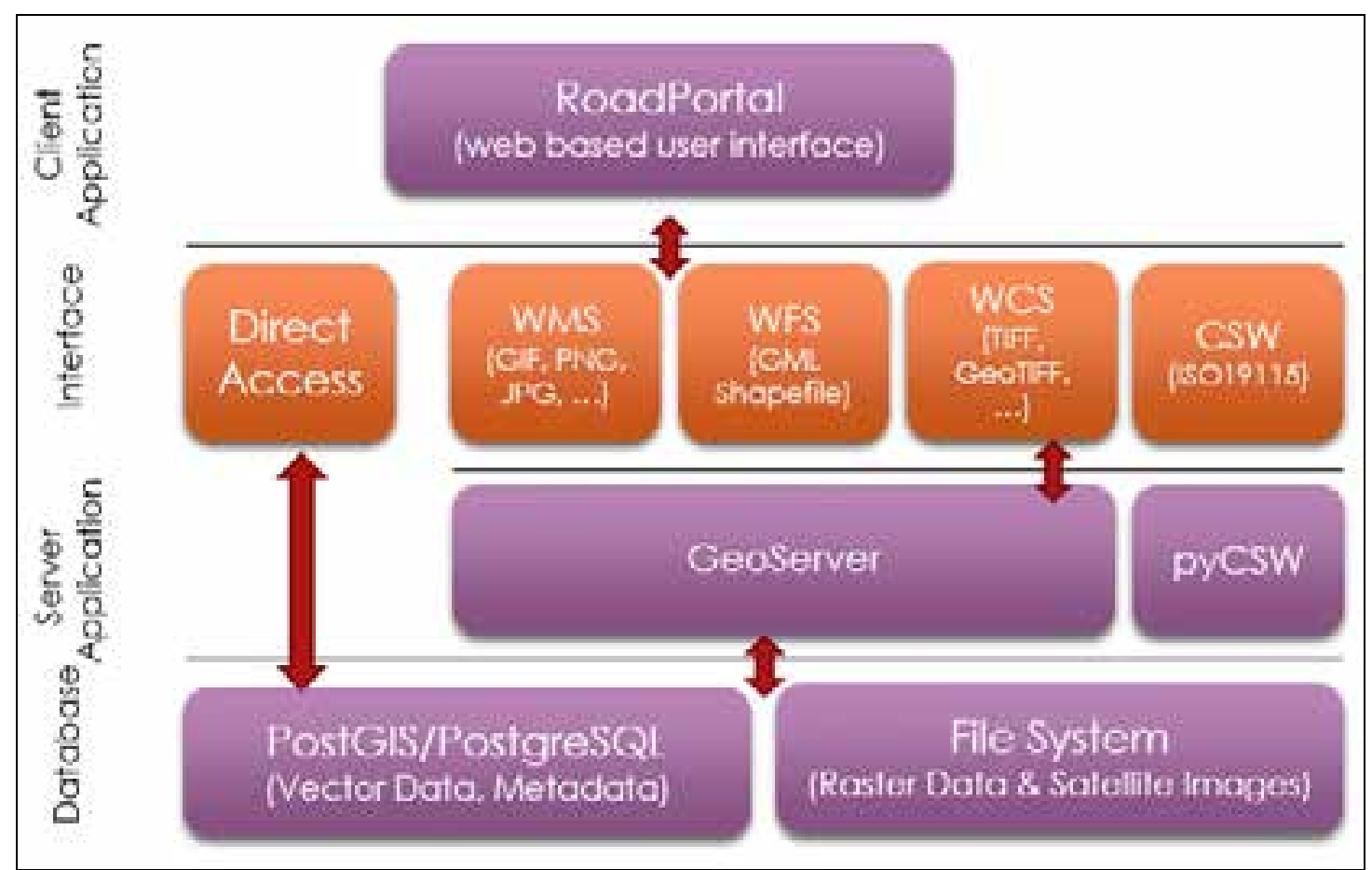

Gambar 1. Bagian Pembangunan Aplikasi webGIS

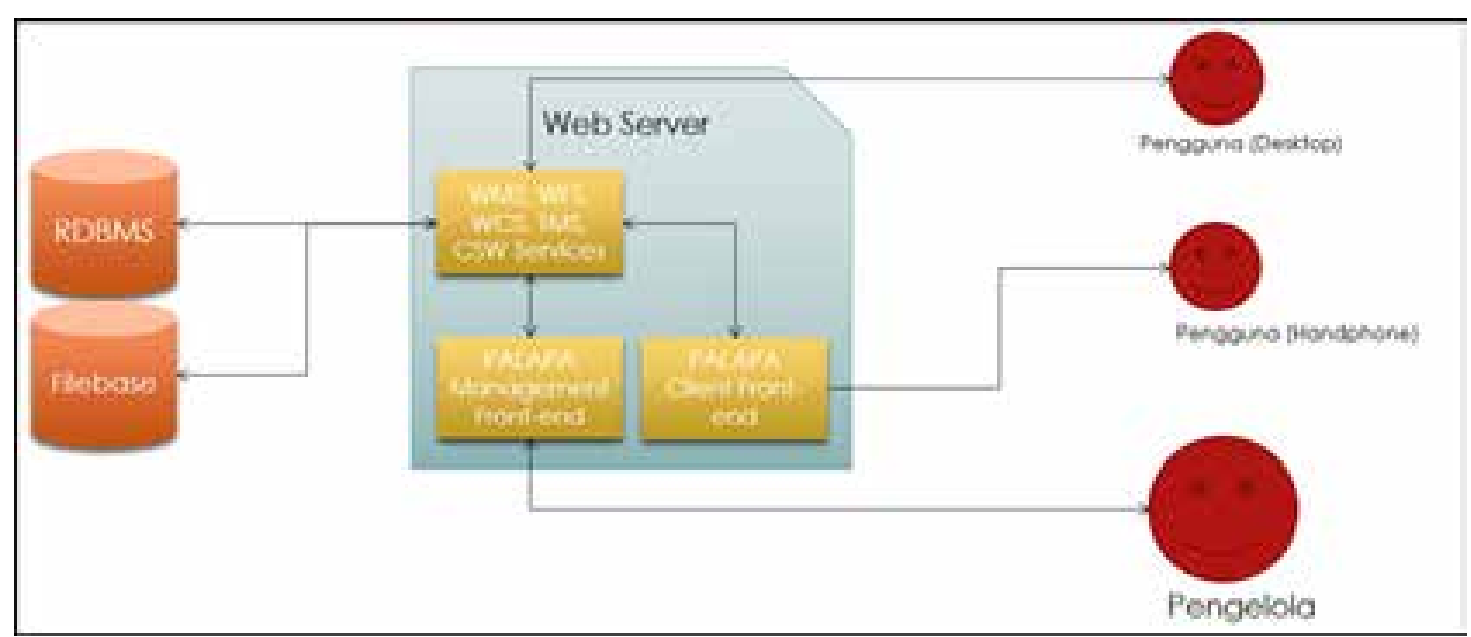

Gambar 2. Alur Pembangunan webGIS Pertanian Organik Provinsi Bali 
Pada tahapan selanjutnya, alur sistem dimulai dari back-end (file base dan DBMS) menuju pengolahan pada web server, mencakup pembangunan management front-end untuk administrator/pengelola dan client front-end untuk pengguna. Pengguna dapat mengakses webgis melalui komputer (desktop) dan telepon genggam (hp). Gambar 2 menunjukkan alur pembangunan sistem Webgis yang dilakukan.

Perangkat lunak aplikasi berbasis web menggunakan platform WebGIS opensource sehingga tidak akan ada benturan dalam masalah hak cipta/hak pengguna. Platform WebGIS opensource adalah platform web yang tidak berbayar (gratis) sehingga akan memudahkan dalam instalasi dan tanpa biaya tambahan.

Pada perangkat lunak aplikasi berbasis web yang dibangun dilengkapi dengan beragam fitur yang memudahkan untuk analisis secara spasial (Gambar 3). Fitur tersebut meliputi view layer peta, fitur cetak, menggeser peta, informasi, pengukuran panjang dan luas, memperbesar dan memperkecil (zoom in dan zoom out), menampilkan legenda peta, fitur informasi mengenai layer peta yang ditampilkan dan atribut atau keterangan yang mengiringinya, serta fitur download layer peta dan metadatanya.

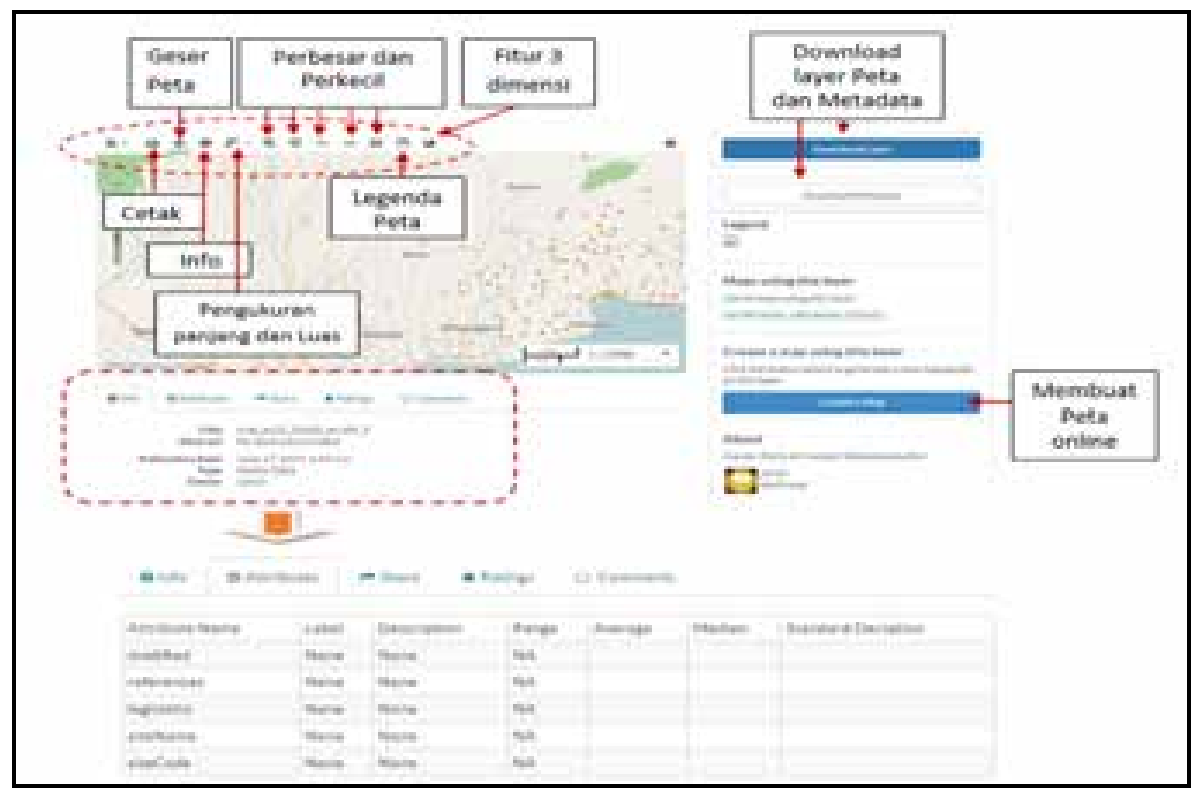

Gambar 3. Fitur Sistem yang Dikembangkan 
Pada perangkat lunak aplikasi berbasis web yang dibangun dilengkapi dengan fitur sharing data sehingga memudahkan untuk memindahkan data. Fitur sharing bisa dimanfaatkan untuk mengirim data melalui email ataupun media sosial. Gambar 4 menunjukkan fitur sharing data yang dimaksud.

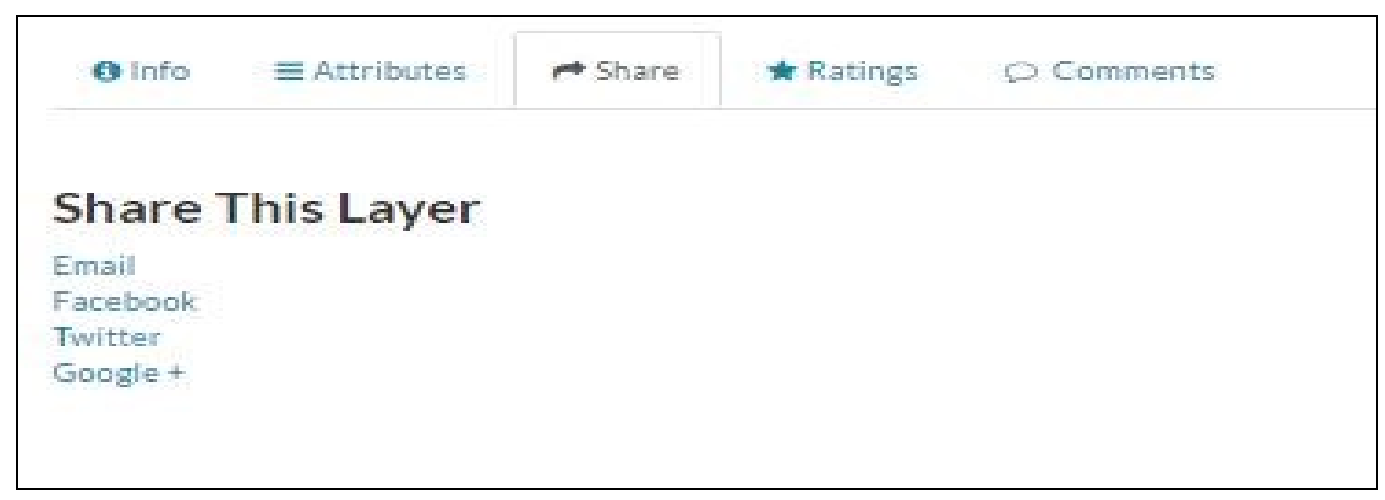

Gambar 4. Fitur Sharing Data pada Sistem yang Akan Dikembangkan

Pada perangkat lunak aplikasi berbasis web yang dibangun dilengkapi dengan fitur pembuatan peta secara online. Fitur tersebut dilengkapi dengan fitur identifikasi atribut peta, query peta, pengukuran panjang dan luas, editing layer peta. Gambar 5 menampilkan fitur pembuatan peta online termasuk editing data.

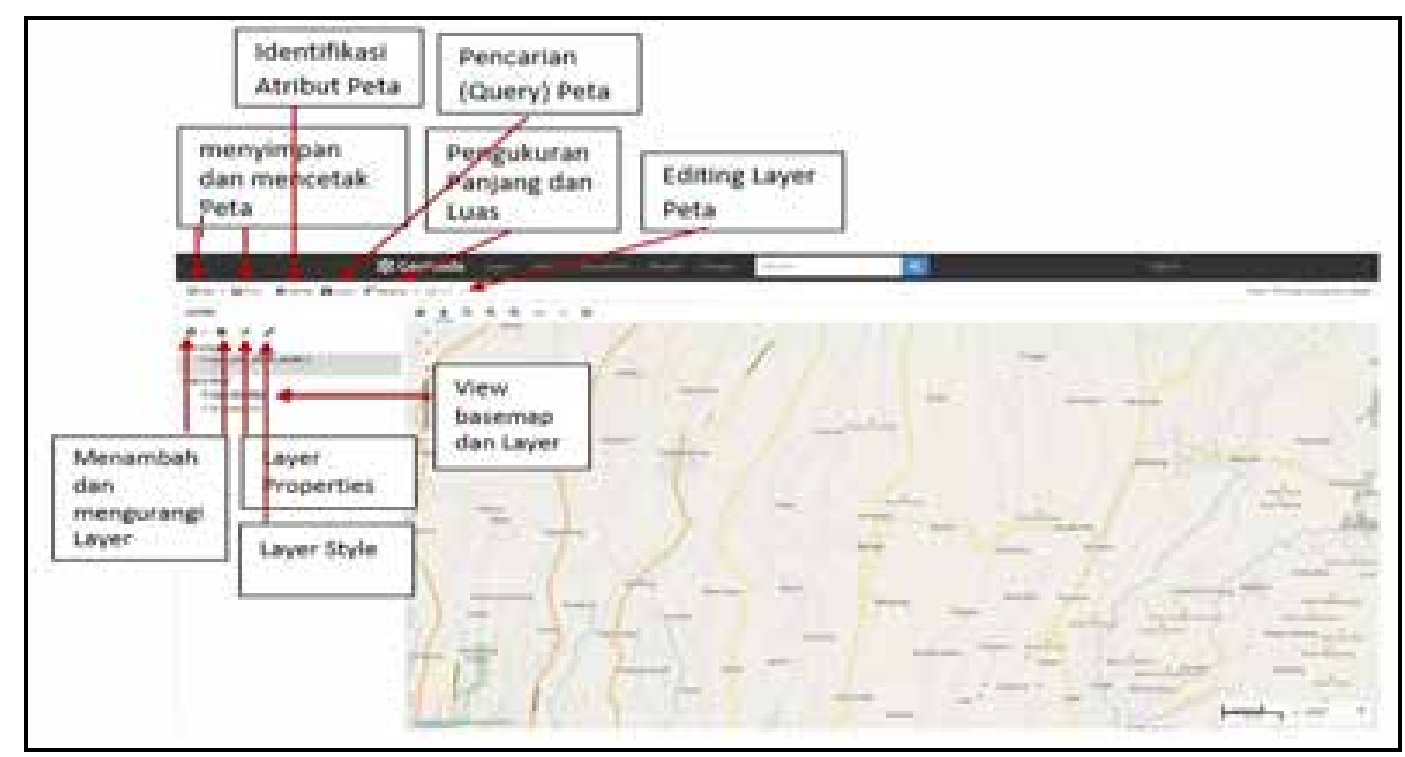

Gambar 5. Fitur Pembuatan Peta Online yang Akan Dikembangkan 
Fitur Basemap (Citra Dasar) yang dinamis dan dapat diubah-ubah. Fitur ini dapat mengganti citra dasar dari openstreet map, bing map hingga google satellite dan peta rupa bumi Indonesia. Gambar 6 menampilkan fitur tersebut.

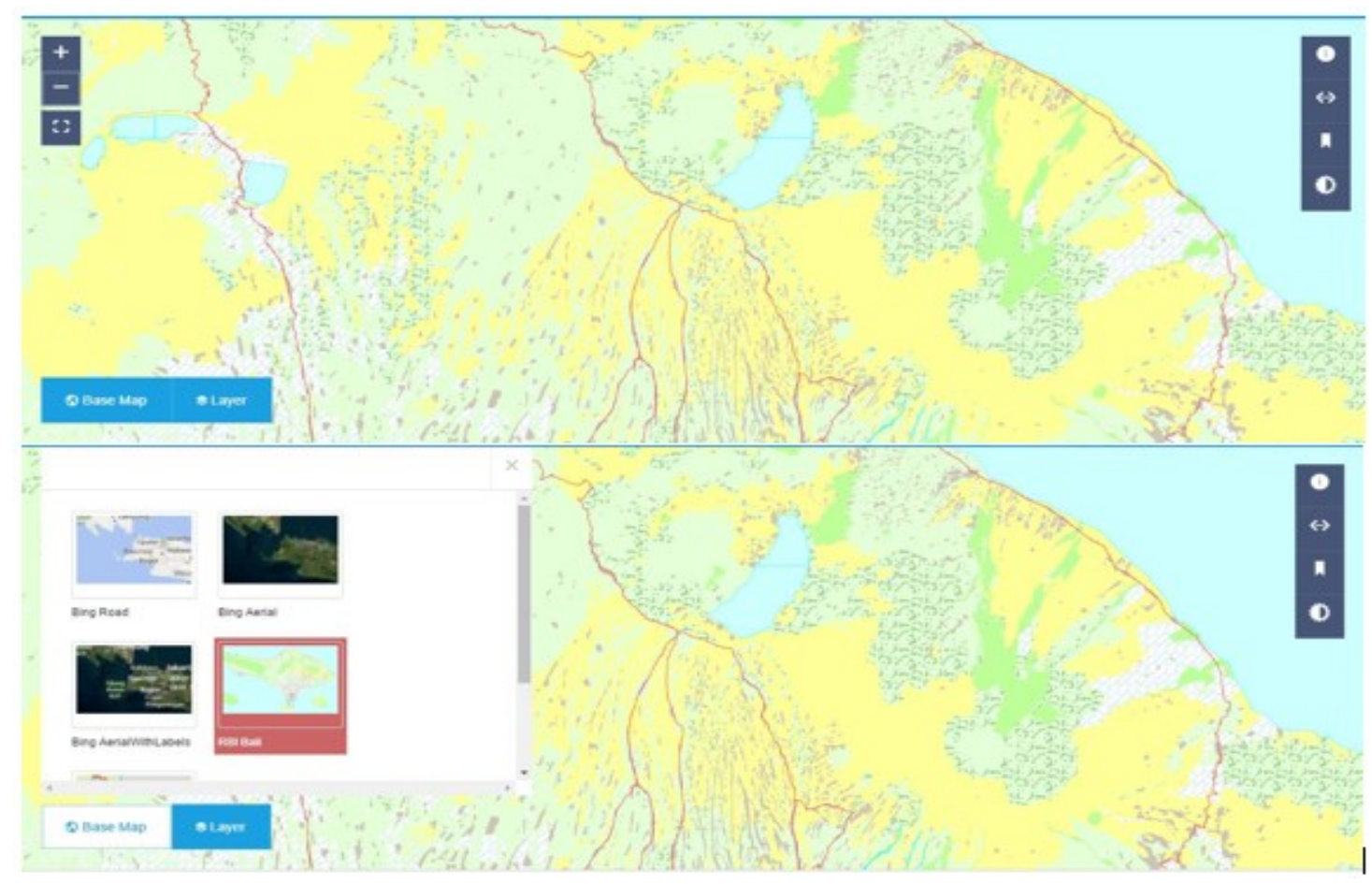

Gambar 6. Fitur Basemap (Citra Dasar) yang Dinamis

Selain berbagi data spasial, sistem yang dikembangkan juga mampu untuk berbagi dokumen secara online, baik dokumen dalam format, Microsoft office, opendata sheet, dan lainnya. Sistem dikembangkan secara lengkap untuk bisa melihat, editing dan berbagi termasuk pembuatan peta. Gambar 7 menunjukkan fitur tersebut. 


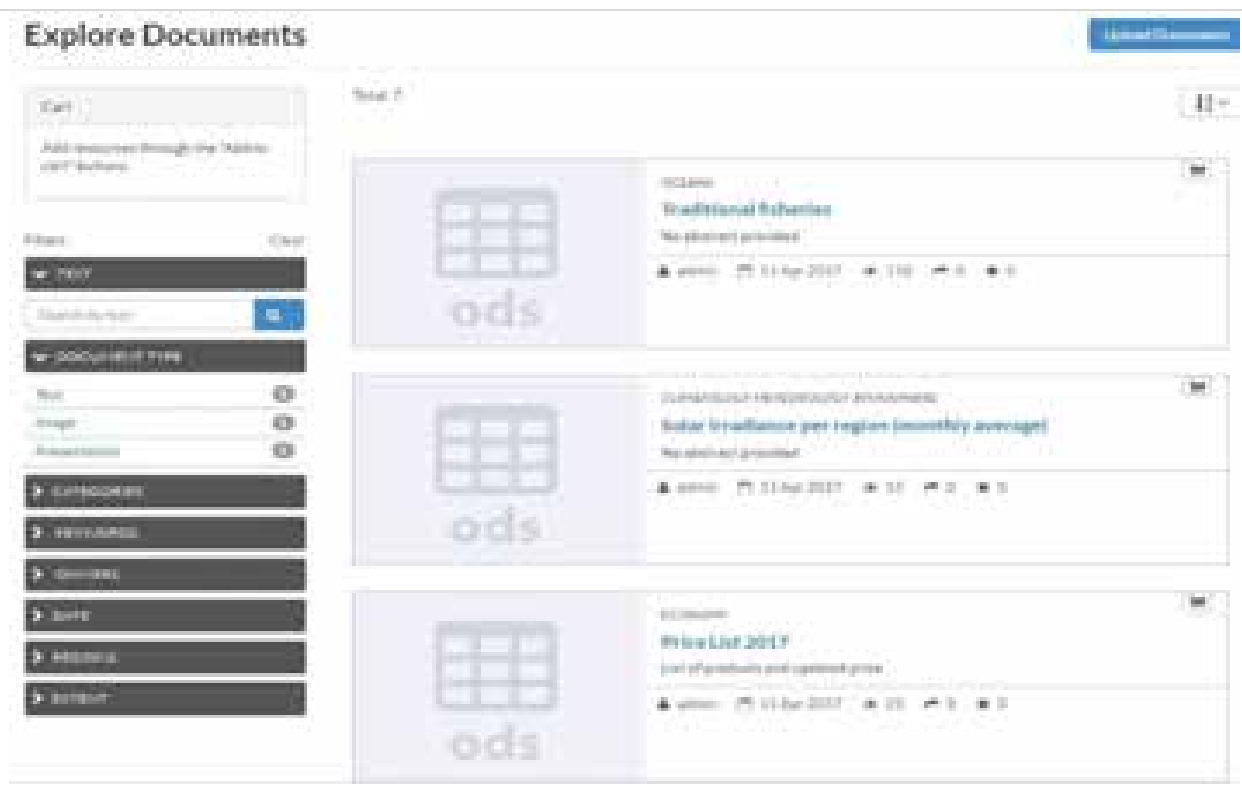

Gambar 7. Fitur Upload, Berbagi dan Download Dokumen

\section{HASIL DAN PEMBAHASAN}

\section{Kondisi Kekinian Sistem Pertanian Organik di Bali}

Budidaya pertanian organik telah diterapkan oleh sebagian kecil (sekitar $8,5 \%$ ) petani (gapoktan) yang ada di Bali. Namun, jumlah petani organik semakin menurun yang mengindikasikan adanya kendala yang dihadapi dalam melaksanakan sistem budidaya organik di Bali. Kendala tersebut bisa bersifat eksternal terutama berkaitan dengan regulasi serta ketersediaan saprodi, teknologi, harga produk, dan pemasaran produk.

Pelaksanaan suatu sistem secara luas di masyarakat memerlukan dukungan kebijakan dan regulasi. Kebijakan dan regulasi nasional yang terhubung dengan sistem pertanian organik telah disiapkan sejak tahun 1992 sampai dengan diberlakukannya Permentan Nomer 64 Tahun 2013 tentang Sistem Pertanian Organik. Pada tatanan Pemerintah Daerah di Bali, peraturan daerah yang mengatur pelaksanaan sistem pertanian organik adalah Perda Nomer 18 Tahun 2019. Peraturan tersebut secara legal telah menguatkan upaya untuk mengembangkan sistem pertanian organik selanjutnya di wilayah Provinsi Bali.

Dinas Pertanian, Tanaman Pangan, Hortikultura dan Perkebunan Provinsi Bali tahun 2014-2017 mencatat 80 kelompok tani dan gabungan kelompok tani yang melaksanakan budidaya pertanian organik. Berdasarkan 
pengembangan dilapangan, diperoleh 106 responden pelaku usahatani organik. Dari hasil survei lapang, diketahui bahwa pertanian organik paling banyak dilakukan di Kabupaten Buleleng yang kemudian disusul oleh Kabupaten Tabanan dan Bangli. Jumlah terbanyak jenis komuditas yang dibudidayakan secara organik terdapat di Kabupaten Buleleng, Kabupaten Gianyar dan Tabanan (Gambar 8).
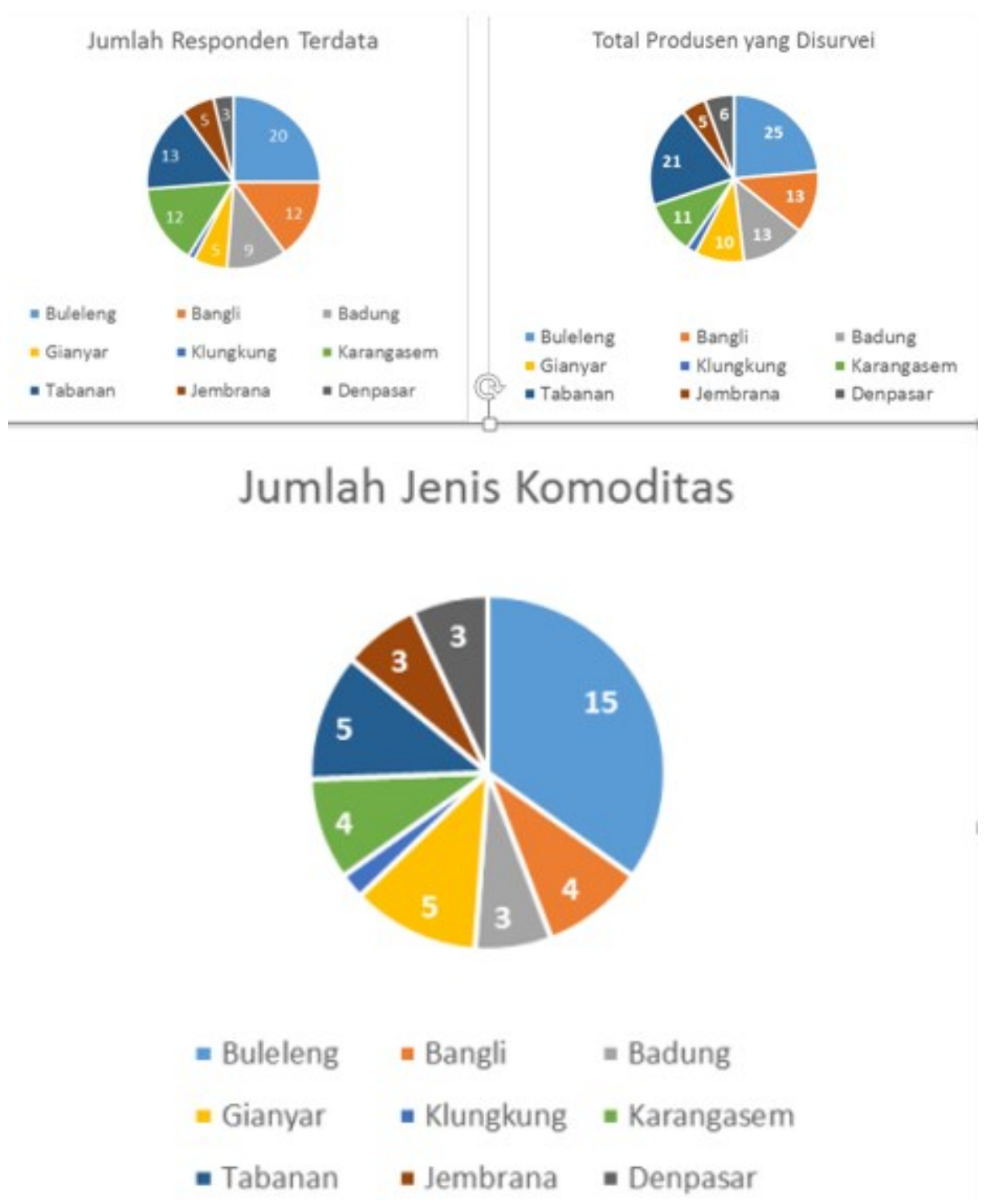

Gambar 8. Jumlah Responden dan Jenis Komoditas Organik di Provinsi Bali

Dari 106 responden yang disurvei (Tabel 8), ditemukan 68 pelaku usahatani organik, 16 di antaranya pernah memperoleh sertifikat Prima 3 tetapi hanya 1 sertifikat yang masih berlaku. Sejumlah 27 pelaku usahatani pernah 
memiliki sertifikat organik yang diberikan oleh Lesos atau Control Union dan 9 di antaranya masih berlaku. Penurunan jumlah pelaku usahatani yang memiliki sertifikat yang aktif menunjukkan adanya kendala internal dan eksternal dalam keberlanjutan pelaksanaan sistem pertanian organik di Bali.

Tabel 1. Data Responden Pelaku Usahatani Organik

\begin{tabular}{|c|c|c|c|c|c|c|c|}
\hline \multirow{2}{*}{ Kabupaten } & \multirow{2}{*}{$\begin{array}{c}\text { Jumlah } \\
\text { Responden } \\
\text { Terdata }\end{array}$} & \multirow{2}{*}{$\begin{array}{c}\text { Jumlah } \\
\text { Responden yang } \\
\text { Disurvei }\end{array}$} & \multirow{2}{*}{$\begin{array}{l}\text { Jumlah } \\
\text { Produsen } \\
\text { Organik }\end{array}$} & \multicolumn{2}{|c|}{ Prima 3} & \multicolumn{2}{|c|}{ Organik } \\
\hline & & & & Total & Aktif & Total & Aktif \\
\hline Buleleng & 20 & 25 & 16 & 7 & 1 & 4 & 2 \\
\hline Bangli & 12 & 13 & 10 & 4 & & 1 & 0 \\
\hline Badung & 9 & 13 & 8 & 0 & & 2 & 2 \\
\hline Gianyar & 5 & 10 & 6 & 0 & & 3 & 0 \\
\hline Klungkung & 1 & 2 & 1 & 1 & & 0 & 0 \\
\hline Karangasem & 12 & 11 & 9 & 1 & & 5 & 0 \\
\hline Tabanan & 13 & 21 & 12 & 2 & & 8 & 3 \\
\hline Jembrana & 5 & 5 & 4 & 0 & & 2 & 2 \\
\hline Denpasar & 3 & 6 & 2 & 1 & & 0 & 0 \\
\hline Jumlah & 80 & 106 & 68 & 16 & & 27 & 9 \\
\hline
\end{tabular}

Jenis komoditas yang memperoleh sertifikat organik adalah bawang merah, buah naga, jahe, manggis, padi, pisang hijau Taiwan, salak, sayuran, dan tanaman hias (Tabel 3.2). Jenis komoditas yang luas tanamnya terbesar adalah sayuran (> 13 ha) dengan kapasitas produksi 6,1 ton/panen. Komoditas yang paling banyak diproduksi sepanjang tahun adalah, salak, manggis, dan jahe. Dibandingkan dengan kebutuhan masyarakat di Bali, luas tanam dan kapasitas produksi komoditas organik sangat tidak memadai. Kebutuhan yang ditujukan untuk keperluan ekspor secara berkesinambungan sangat sulit untuk diwujudkan sehingga diperlukan perluasan areal tanam dan pembentukan sentra produksi.

Permentan Nomer 50 tahun 2012 tentang Pengembangan Kawasan Pertanian memuat 40 komoditas unggulan nasional yang hendak dikembangkan kawasannya secara spesifik di seluruh wilayah Indonesia. Komoditas yang akan dikembangkan kawasan budidayanya di Bali adalah padi diseluruhwilayah kabupaten dan kota (untuk komoditas tanaman pangan), bawang merah merupakan satu-satunya hortikultura yang kawasannya 
dikembangkan di Kabupaten Bangli, serta kawasan budidaya ternak sapi dapat dilakukan diseluruh kabupaten kecuali Kota Denpasar. Dengan demikian, pengembangan kawasan pertanian untuk memproduksi komoditas padi dan bawang merah organik yang telah memperoleh sertifikat organik secara teknokratik telah sejalan dengan kebijakan pusat sesuai dengan Permentan Nomer 50 tahun 2012. Disisi lain, komoditas lainnya yang saat ini tidak diprioritaskan untuk dibudidayakan di Bali berdasarkan Permentan Nomer 50 tahun 2012, dapat diupayakan menjadi komoditas unggulan kompetitif terutama untuk tujuan ekspor.

Tabel 2. Data Kalender Produksi Komoditas Organik di Provinsi Bali

\begin{tabular}{|c|c|c|c|c|c|c|c|c|c|c|c|c|c|c|c|c|}
\hline \multirow{2}{*}{ Nambe } & \multicolumn{12}{|c|}{ aph } & \multirow{2}{*}{ man: } & \multirow{2}{*}{$+a$} & \multirow{2}{*}{ Arate: } & \multirow{2}{*}{$\ln$} \\
\hline & $=$ & $P=$ & the & so & $\omega$ & $\operatorname{sen}$ & $2 a$ & 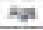 & Ster & at & $1=$ & Den & & & & \\
\hline$\Leftrightarrow$ & & & & & & & & & & & & & Atmbites & 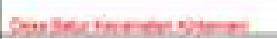 & 13:5 & $3 n$ \\
\hline Antres. & & & & & & & & & & & & & Botrespereith & 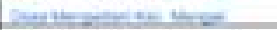 & thas & $=\pi$ \\
\hline an & & & & & & & & & & & & & vencests & 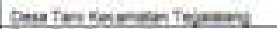 & ngom & $18 \mathrm{mg}$ \\
\hline \multirow{2}{*}{$\infty=\infty$} & & & & & & & & & & & & & onsetentwues & 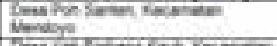 & 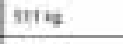 & 10 \\
\hline & & & & & & & & & & & & & Hesefruvater. & 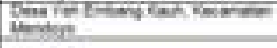 & 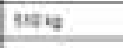 & itren. \\
\hline \multirow{2}{*}{ Wron } & & & & & & & & & & & & & Stedenidertale & 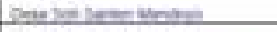 & netre & in \\
\hline & & & & & & & & & & & & & $4+5 \times=$ & 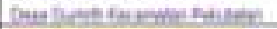 & 1s:zue & 1난 \\
\hline \multirow{7}{*}{$\infty$} & & & & & & & & & & & & & 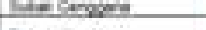 & & 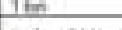 & $\sin$ \\
\hline & & & & & & & & & & & & & Nateris & 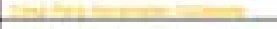 & 19:4ats & tst. \\
\hline & & & & & & & & & & & & & 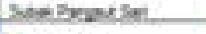 & 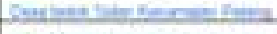 & war & Tnes. \\
\hline & & & & & & & & & & & & & Semants & 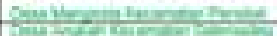 & $31=$ & $100 \pi$ \\
\hline & & & & & & & & & & & & & 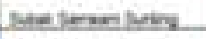 & Hers & Wre & 16 \\
\hline & & & & & & & & & & & & & Hoseyy & 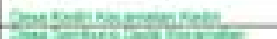 & then & mene \\
\hline & & & & & & & & & & & & & ate & tindes & t21m & Xite \\
\hline Nangerse & & & & & & & & & & & & & hates & & bavese & the \\
\hline
\end{tabular}

\begin{tabular}{|c|c|c|c|c|c|c|c|c|c|c|c|c|c|c|c|c|}
\hline \multirow{2}{*}{ Ondten } & \multicolumn{12}{|c|}{ Nent } & \multirow{2}{*}{ Nodwero } & \multirow{2}{*}{$\operatorname{Latan}$} & \multirow{2}{*}{ Arodice } & \multirow{2}{*}{$\sum_{T=1}$} \\
\hline & $=$ & $\pi=$ & $\omega$ & Aq & un & $\mathrm{An}$ & 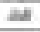 & $\infty$ & se & $\infty$ & the & In & & & & \\
\hline \multirow{5}{*}{ san } & & & & & & & & & & & & & 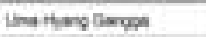 & Quen anjolations & $0 t \mathrm{~m}$ & $15 \mathrm{sin}$ \\
\hline & & & & & & & & & & & & & 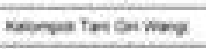 & 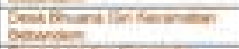 & axen & $a t$ \\
\hline & & & & & & & & & & & & & nowere tow weons & 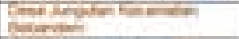 & titan & 20 \\
\hline & & & & & & & & & & & & & 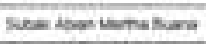 & 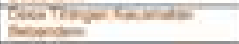 & $2 \mathrm{~km}$ & 10 \\
\hline & & & & & & & & & & & & & 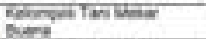 & 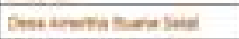 & ban-13n & ense \\
\hline \multirow{5}{*}{ Sarven: } & & & & & & & & & & & & & dean infors & 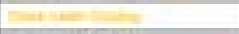 & $\theta=$ & 134 \\
\hline & & & & & & & & & & & & & 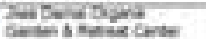 & 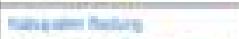 & $=4$ & ta \\
\hline & & & & & & & & & & & & & 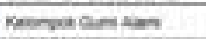 & gene & salobote & 26 \\
\hline & & & & & & & & & & & & & $\ln _{0 \rightarrow 3}$ & 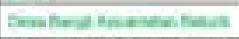 & $2800=$ & $n \infty$ \\
\hline & & & & & & & & & & & & & men inets: & 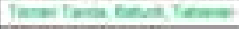 & Silatghen & Den \\
\hline $\lim$ & & & & & & & & & & & & & Serson & 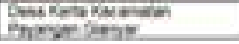 & 300 ienote & ses \\
\hline
\end{tabular}

Potensi bahan baku pupuk organik yang tersebar di Bali dihitung berdasarkan data populasi ternak ayam, sapi, dan kambing di Bali (Tabel 3). Kotoran ternak sapi secara kuantitas paling potensial untuk dikembangkan sebagai pupuk organik. Namun, dari segi kualitas penggunaan pupuk kandang ayam dan kambing sangat memungkinkan untuk dimanfaatkan 
Tabel 3. Potensi Bahan Baku Pupuk Organik di Bali

[Sumber: Dihitung berdasarkan data populasi ternak (BPS Bali, 2018)]

\begin{tabular}{lllc}
\hline No & & Jenis Ternak & Potensi Kotoran Ternak (ton/tahun) \\
1 & Sapi & & 946.000 \\
2 & Kambing & & 156,24 \\
3 & Ayam & \multirow{2}{*}{ Jumlah } & 5.760 \\
& & & $951.916,24$ \\
\hline
\end{tabular}

Dalam budidaya pertanian organik, pupuk merupakan salah satu sarana pendukung utama yang menentukan jumlah produksi komuditas. Jumlah pupuk organik tergantung dari jumlah bahan baku yang tersedia. Provinsi Bali memiliki potensi bahan baku pupuk organik yang besar dari pupuk kandang (Tabel 3). Produksi kotoran ternak tersebut merupakan bahan baku utama pengolahan pupuk organik di beberapa unit usaha usaha di Bali yang dikelola oleh simantri, gapoktan, kelompok ternak, dan subak. Total jumlah produksi pupuk organik yang dapat dihasilkan dari empat kelompok tersebut disajikan dalam Tabel 4. Produksi pupuk organik tersebut telah dipasarkan hampir diseluruh daerah di Bali yang mencerminkan adanya keuntungan ekonomi yang diperoleh oleh pemilik usaha dan bermanfaat bagi pengguna.

Tabel 4. Unit Usaha Pengolahan Pupuk Organik di Bali

\begin{tabular}{|c|c|c|c|c|c|c|c|c|c|c|}
\hline No. & Nama Kelompok & Alanut & Angoda & $\begin{array}{l}\text { Thun } \\
\text { Beidn }\end{array}$ & Sambin & $\begin{array}{l}\text { Prodaksi } \\
\text { Oontatuni) }\end{array}$ & Kompeses: & Stanter & $\begin{array}{l}\text { Kaya } \\
\text { Rupak }\end{array}$ & Diatrous: \\
\hline 1 & $\begin{array}{l}\text { Koovmi KuAT (B.osk } \\
\text { Guana) }\end{array}$ & 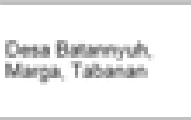 & $\underset{\text { (nubak) }}{522 \text { orang }}$ & 2002 & 196 & 360 & 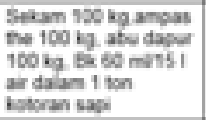 & Beaca & $\begin{array}{l}1000 \mathrm{k} \text {, QS } \\
\text { agleminin) }\end{array}$ & $\begin{array}{l}\text { Twanan is } \\
\text { Denganis }\end{array}$ \\
\hline 2 & 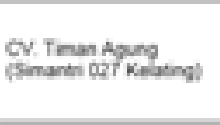 & $\begin{array}{l}\text { Den Sanging Ds } \\
\text { Kelasing Kerambian } \\
\text { Tabanin }\end{array}$ & 20 crang & 2098 & 10 & 3600 & 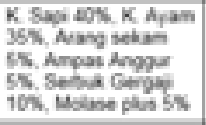 & $\begin{array}{l}\text { Sater } \\
\text { Molate } \\
\text { Lanumg }\end{array}$ & $\begin{array}{l}500010 \mathrm{~kg} \\
12000 / 20 \mathrm{~kg} \\
30.000 / 40 \mathrm{gg}\end{array}$ & Seturinh flat \\
\hline 3 & $\begin{array}{l}\text { Gapektan Bina Kays } \\
\text { fist }\end{array}$ & $\begin{array}{l}\text { Oe MusiGendgat } \\
\text { Buleteng }\end{array}$ & 180 arang & 2090 & 180 & 9100 & $\begin{array}{l}\text { Kotorm sap. Eve. } \\
\text { Batha Gula }\end{array}$ & ENA & $\begin{array}{l}30,000 / 42 \\
k 9\end{array}$ & $\begin{array}{l}\text { Buleleng } \\
\text { dan } \\
\text { Dengants }\end{array}$ \\
\hline 4 & 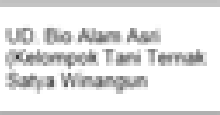 & $\begin{array}{l}\text { Br. Tonghas, Da. } \\
\text { Tanglan, Nounghung }\end{array}$ & 25 Orang & 2006 & wes & 1.260 & 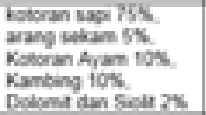 & $\begin{array}{l}\text { uol } \\
\text { Bum } \\
\text { Olanak. } \\
\text { Senti) }\end{array}$ & $\begin{array}{l}1000 \mathrm{k} \text {. } \\
\text { Thiobleima } \\
\text { 1500ikg }\end{array}$ & $\begin{array}{l}\text { Selunh Bat } \\
\text { lectal } \\
\text { Jembrans }\end{array}$ \\
\hline
\end{tabular}

Sistem pertanian organik di Bali tergolong berkembang dengan peroleh skor total sebesar 1243 dengan ditribusi skor total 1192 hingga 1872 (Tabel 5). Penilaian tersebut diperoleh dari tipologi usaha tani yang dilakukan oleh pelaku pertanian organik di Bali. Profil sistem pertanian organik dinilai dengan menjumlahkan hasil skor sesuai dengan wawancara terhadap seluruh kelompok tani organik di Bali. 
Tabel 5. Profil Sistem Pertanian Organik [Sumber data: hasil pengolahan data primer]

\begin{tabular}{cccc} 
No & Skor Total & Distribusi skor total & Kategori \\
1 & & $511-1191$ & Pemula \\
2 & 1243 & $1192-1872$ & Berkembang \\
3 & & $1873-2555$ & Maju \\
\hline
\end{tabular}

Tipologi usaha tani pertanian organik di Bali dinilai dari beberapa aspek yang menjadi parameter dalam penilaian suatu tipologi dari usaha tani organik. Hasil yang disajikan dalam Tabel 6 menunjukkan, bahwa parameter kuantitas modal menjadi suatu tolak ukur yang paling utama dalam melakukan usaha tani organik. Kuantitas modal memperoleh nilai skor paling rendah, yaitu sebesar 89, dengan sebaran jumlah responden yang memiliki jumlah modal $<\mathrm{Rp}$ 30.000 .000 sebanyak 67 orang $(91,8 \%)$. Sebagian besar modal yang digunakan oleh petani merupakan modal mandiri. Sistem produksi yang diterapkan tergolong berkelanjutan dengan mengandalkan tenaga kerja keluarga dan buruh tani sejumlah dominan 1-5 orang. Walaupun usahatani dilakukan dengan teknologi tradisional, modern atau tepat guna, tetapi sebagian besar petani mengandalkan teknologi tradisional dalam melakukan usahatani. Sebagian pelaku usahatani organik telah memiliki mitra tetap sehingga memiliki pendapatan yang relatif tetap dan pasti, tetapi sebagian lainnya masih mencari pelanggan. Dari 73 responden yang didata (Tabel 6), jumlah petani yang masih dalam tahap mencari mitra adalah 31 orang.

Tabel 6. Tipologi Usahatani Pertanian Organik di Bali

[Sumber data: hasil pengolahan data primer]

\begin{tabular}{|c|c|c|c|c|}
\hline Parameter & Skor & Kategori & $\begin{array}{l}\text { Jumlah } \\
\text { responden } \\
\text { (Orang) }\end{array}$ & $\begin{array}{c}\text { Presentase } \\
(\%)\end{array}$ \\
\hline \multirow{3}{*}{ Kuantitas Modal } & \multirow{3}{*}{89} & $<\operatorname{Rp} 30.000 .000$ & 67 & 91,8 \\
\hline & & $>\operatorname{Rp} 30.000 .000-65.000 .000$ & 4 & 5,5 \\
\hline & & >Rp $66.000 .000-100.000 .000$ & 2 & 2,7 \\
\hline \multirow{2}{*}{ Sistem Produksi } & \multirow[b]{2}{*}{309} & Mencoba & 11 & 15,1 \\
\hline & & Sesuai pesanan & 6 & 8,2 \\
\hline
\end{tabular}




\begin{tabular}{|c|c|c|c|c|}
\hline & & Berkelanjutan & 61 & 83,6 \\
\hline \multirow{3}{*}{ Modal Kerja } & \multirow{3}{*}{93} & Sendiri & 63 & 86,3 \\
\hline & & Sendiri + Pinjaman & 10 & 13,7 \\
\hline & & Pinjaman & 0 & 0,0 \\
\hline \multirow{3}{*}{ Jenis Tenaga Kerja } & \multirow{3}{*}{187} & Keluarga & 25 & 34,2 \\
\hline & & Keluarga + Buruh Tani & 39 & 53,4 \\
\hline & & Buruh Tani & 9 & 12,3 \\
\hline \multirow{3}{*}{ Jumlah Tenaga Kerja } & \multirow{3}{*}{205} & 1 - 2 Orang & 26 & 35,6 \\
\hline & & $3-5$ Orang & 26 & 35,6 \\
\hline & & $>5$ Orang & 21 & 28,8 \\
\hline \multirow{3}{*}{$\begin{array}{l}\text { Penggunaan } \\
\text { teknologi }\end{array}$} & \multirow{3}{*}{175} & Tradisional & 39 & 53,4 \\
\hline & & Modern & 17 & 23,3 \\
\hline & & Teknologi Tepat Guna & 17 & 23,3 \\
\hline \multirow{3}{*}{$\begin{array}{l}\text { Proses kemitraan } \\
\text { usaha }\end{array}$} & \multirow{3}{*}{223} & Sedang mencari pelanggan & 29 & 39,7 \\
\hline & & Sedang Berlanjut & 13 & 17,8 \\
\hline & & Sudah Bermitra (MOU) & 31 & 42,5 \\
\hline
\end{tabular}

Dari sisi kapasitas manajerial, petani di Bali yang melakukan sistem budidaya organik tergolong petani maju dalam manajerial sistem pertanian, dengan nilai skor 9227 (Tabel 7). Petani tersebut memiliki kemampuan untuk mengakses pengetahuan dan teknologi serta mengasah keterampilan secara mandiri.

Tabel 7. Kapasitas Manajerial Petani dalam Sistem Budidaya Pertanian Organik [Sumber data : hasil pengolahan data primer]

\begin{tabular}{cccc}
\hline No & Skor Total & Distribusi skor total & Kategori \\
1 & & $2263-5279$ & Inisiasi \\
2 & 9227 & $5280-8297$ & Berkembang \\
3 & & $8298-11315$ & Maju \\
\hline
\end{tabular}

Tabel 8. Teknologi Pasca Panen yang Dilakukan dalam Sistem Pertanian Organik

\begin{tabular}{lclcc}
\multicolumn{1}{c}{ Parameter } & Skor & Kategori & $\begin{array}{c}\text { Jumlah responden } \\
\text { (Orang) }\end{array}$ & Presentase (\%) \\
Sortasi Pasil Panen & 229 & Tidak Ada & 34 & 46,5 \\
& & Ada & 39 & 53,5 \\
$\begin{array}{l}\text { Tempat/Gudang } \\
\text { Penyimpanana Hasil }\end{array}$ & 209 & Tidak Ada & 39 & 53,5 \\
Sarana Prosesing Hasil & 205 & Ada & 34 & 45,5 \\
panen & \multirow{2}{*}{ Tidak Ada } & 40 & 54,7 \\
Sarana & 205 & Ada & 33 & 45,3 \\
\hline
\end{tabular}




\begin{tabular}{|c|c|c|c|c|}
\hline Pendingin/Pengawet & & Ada & 33 & 45,3 \\
\hline \multirow{2}{*}{ Cara Pengawetan Hasil } & \multirow{2}{*}{185} & Tidak Ada & 45 & 61,7 \\
\hline & & Ada & 28 & 38,3 \\
\hline \multirow{2}{*}{$\begin{array}{l}\text { Pengendalian OPT Pasca } \\
\text { Panen }\end{array}$} & \multirow{2}{*}{205} & Tidak Ada & 40 & 54,7 \\
\hline & & Ada & 33 & 45,3 \\
\hline \multirow{2}{*}{$\begin{array}{l}\text { Sarana Pengepakan } \\
\text { Sesuai standar }\end{array}$} & \multirow{2}{*}{189} & Tidak Ada & 44 & 60,3 \\
\hline & & Ada & 29 & 39,7 \\
\hline
\end{tabular}

Petani organik di Bali lebih banyak melakukan pengendalian organisme pengganggu tumbuhan (OPT) secara fisik dan mekanik. Sebagian besar di antara petani $(>80 \%)$ tidak melakukan pengendalian secara hayati (Tabel 8.) karena terkendala ketersediaan bahan dan teknologi yang dikuasai.

Kendala merupakan faktor penting yang harus diperhitungkan dalam melaksanakan sistem pertanian organik di Bali. Beberapa faktor merupakan pembatas penting dalam menyukseskan pengembangan sistem pertanian organik di Bali (Tabel 10). Kendala terbesar yang dihadapi adalah status saprodi yang tidak bersertifikat $(82,2 \%)$. Kendala penting berikutnya adalah sulit memperoleh sertifikat organik dan registrasi lahan (Tabel 11).

Tabel 10. Kendala Sistem Pertanian Organik

\begin{tabular}{cccc}
\hline Nomor & Skor Total & Distribusi skor total & Kategori \\
1 & & $730-1702$ & Sangat Penting \\
2 & 1466 & $1703-1675$ & Penting \\
3 & & $1676-3650$ & Tidak Penting \\
\hline
\end{tabular}

Tabel 11. Faktor yang Mempengaruhi Kendala Sistem Pertanian Organik

\begin{tabular}{lclcc}
\hline \multicolumn{1}{c}{ Parameter } & Skor & \multicolumn{1}{c}{ Kategori } & $\begin{array}{c}\text { Jumlah } \\
\text { responden } \\
\text { (Orang) }\end{array}$ & $\begin{array}{c}\text { Presentase } \\
\text { (\%) }\end{array}$ \\
Ketersediaan saprodi & \multirow{2}{*}{165} & Sulit Tersedia & 29 & 39,7 \\
& & Cukup Tersedia & 42 & 57,5 \\
& & Mudah Tersedia & 2 & 2,7 \\
Tempat memperoleh & \multirow{2}{*}{205} & Sangat Dekat & 15 & 20,5 \\
saprodi dari lahan & & Dekat & 48 & 65,8 \\
& & Jauh & 10 & 13,7 \\
Distribusi Hasil & \multirow{2}{*}{203} & Mudah & 21 & 28,8 \\
& & Sulit & 36 & 49,3 \\
Kemudahan & \multirow{2}{*}{251} & Sangat Sulit & 16 & 21,9 \\
\hline
\end{tabular}




\begin{tabular}{|c|c|c|c|c|}
\hline \multirow{2}{*}{$\begin{array}{l}\text { memperoleh sertifikasi } \\
\text { produk organik }\end{array}$} & & Sulit & 39 & 53,4 \\
\hline & & Sangat Sulit & 26 & 35,6 \\
\hline \multirow{3}{*}{ Registrasi lahan } & \multirow{3}{*}{249} & Mudah & 10 & 13,7 \\
\hline & & Sulit & 36 & 49,3 \\
\hline & & Sangat Sulit & 27 & 37,0 \\
\hline \multirow{3}{*}{ Harga saprodi } & \multirow{3}{*}{212} & Murah & 11 & 15,1 \\
\hline & & Terjangkau & 54 & 74,0 \\
\hline & & Sangat Mahal & 8 & 11,0 \\
\hline \multirow{3}{*}{ Harga hasil pertanian } & \multirow{3}{*}{154} & Sesuai Harapan & 39 & 53,4 \\
\hline & & Tidak Sesuai Harapan & 27 & 37,0 \\
\hline & & $\begin{array}{l}\text { Sangat Tidak Sesuai } \\
\text { Harapan }\end{array}$ & 7 & 9,6 \\
\hline \multirow{3}{*}{ Status Saprodi } & \multirow{3}{*}{316} & Sedang Proses & 9 & 12,3 \\
\hline & & Sudah tersertifikat & 4 & 5,5 \\
\hline & & Tidak Bersertifikat & 60 & 82,2 \\
\hline \multirow{3}{*}{ Lokasi pemasaran } & \multirow{3}{*}{131} & Dekat & 44 & 60,3 \\
\hline & & Jauh & 12 & 16,4 \\
\hline & & Sangat Jauh & 7 & 9,6 \\
\hline \multirow{3}{*}{ Segmen pasar } & \multirow{3}{*}{153} & Tradisional & 39 & 53,4 \\
\hline & & Modern & 29 & 39,7 \\
\hline & & Internasional & 5 & 6,8 \\
\hline
\end{tabular}

Total kelompok tani yang disurvei dalam kegiatan pertanian organik sejumlah 106 kelompok. Sebagian besar kelompok tersebut merupakan produsen (68 pelaku) yang menghasilkan komoditas pertanian. Responden yang memiliki usaha di bidang jasa budidaya, pengadaan saprodi, dan jasa agrowisata masing-masing hanya 1 pelaku. Responden yang memiliki usaha dalam bidang penanganan hasil panen hanya 2 pelaku (Tabel 12).

Tabel 12.Potensi Pertanian Organik

\begin{tabular}{lcccccc}
\hline Kabupaten & $\begin{array}{c}\text { Total Kelompok } \\
\text { Tani yang di } \\
\text { Survei }\end{array}$ & $\begin{array}{c}\text { Produsen } \\
\text { Organik }\end{array}$ & $\begin{array}{c}\text { Bidang Jasa } \\
\text { Budidaya }\end{array}$ & $\begin{array}{c}\text { Bidang } \\
\text { Saprodi }\end{array}$ & $\begin{array}{c}\text { Penyosohan } \\
\text { Hasil }\end{array}$ & $\begin{array}{c}\text { Jasa } \\
\text { Agrowisata }\end{array}$ \\
\hline Buleleng & 25 & 16 & 1 & 0 & 0 & 0 \\
Bangli & 13 & 10 & 0 & 0 & 0 & 0 \\
\hline Badung & 13 & 8 & 0 & 0 & 0 & 1 \\
Gianyar & 10 & 6 & 0 & 1 & 1 & 0 \\
\hline Klungkung & 2 & 1 & 0 & 0 & 1 & 0 \\
\hline Karangasem & 11 & 9 & 0 & 0 & 0 & 0 \\
\hline Tabanan & 21 & 12 & 0 & 0 & 0 & 0 \\
Jembrana & 5 & 4 & 0 & 0 & 0 & 0 \\
Denpasar & 6 & 2 & 0 & 0 & 0 & 0 \\
\hline Total & $\mathbf{1 0 6}$ & $\mathbf{6 8}$ & $\mathbf{1}$ & $\mathbf{1}$ & $\mathbf{2}$ & $\mathbf{1}$ \\
\hline
\end{tabular}




\section{Potensi Pengembangan Sistem Pertanian Organik di Bali}

Potensi pengembangan sistem pertanian organik di Bali dilihat dari beberapa aspek. Aspek tersebut meliputi pengakuan harga produk pertanian oleh pasar lokal maupun pasar internasional, perolehan sertifikat organik sesuai standar nasional indonesia (SNI) oleh kelompok tani dan aktivitas budidaya pertanian organik. Data dan informasi tersebut diperoleh melalui wawancara terhadap kelompok tani berdasarkan Peraturan Menteri Pertanian No. 64 Tahun 2013 dengan fokus pada luas lahan pertanian dan kapasitas produksi komoditas aktual pernah bersertifikat prima 3 .

Total kelompok tani yang mendapatkan pengakuan harga oleh pasar lokal maupun internasional sebanyak 33 kelompok. Pengakuan harga didukung oleh perolehan sertifikat organik sejumlah 25 kelompok tani dan potensi pengembangan tersebut dilengkapi oleh aktivitas budidaya yang dilakukan petani dari sejumlah 35 kelompok tani (Tabel 13). Kelompok tani yang memiliki potensi organik diukur dari ketiga parameter tersebut (pengakuan harga, sertifikat dan aktifitas budidaya) berada di Kabupaten Buleleng, Bangli, Badung, Gianyar, Karangasem, Tabanan dan Jembrana. Kelompok tani yang tidak mendapatkan nilai dari salah satu dari ketiga kategori tersebut belum tergolong potensial sebagai lokasi pengembangan pertanian organik.

Tabel 13. Potensi Pengembangan Sistem Pertanian Organik oleh Kelompok Tani di Bali

\begin{tabular}{lcccc}
\hline Kabupaten & $\begin{array}{c}\text { Pengakuan } \\
\text { Harga }\end{array}$ & $\begin{array}{c}\text { Sertifikat } \\
\text { Organik }\end{array}$ & $\begin{array}{c}\text { Aktivitas Budidaya } \\
\text { Sesuai Permentan } \\
\mathbf{6 4 / 2 0 1 3}\end{array}$ & Potensi \\
Buleleng & 8 & 4 & 8 & Potensial \\
Bangli & 6 & 1 & 4 & Potensial \\
Badung & 1 & 1 & 3 & Potensial \\
Gianyar & 2 & 3 & 3 & Potensial \\
Klungkung & 1 & 0 & 0 & Belum potensial \\
Karangasem & 1 & 5 & 8 & Potensial \\
Tabanan & 7 & 7 & 5 & Potensial \\
Jembrana & 4 & 4 & 4 & Potensial \\
Denpasar & 3 & 0 & 0 & \\
\hline Total & 33 & 25 & 35 & Potensial \\
\hline
\end{tabular}


Potensi pengembangan pertanian organik memerlukan dukungan ketersediaan lahan. Luas lahan yang dimiliki oleh pelaku pertanian organik di Bali berkisar antara 15 dan $50 \mathrm{Ha}$. Jumlah responden yang memiliki lahan pertanian < $15 \mathrm{Ha}$ sebanyak 72 kelompok dengan persentase $90 \%$, kemudian luas lahan $>16 \leq 30$ Ha sebanyak 4 kelompok dengan nilai $5 \%$, dan luas lahan yang dimiliki oleh petani dari > $30 \mathrm{Ha}$ hingga $50 \mathrm{Ha}$ sebanyak 4 kelompok dengan nilai 5\% (Tabel 14). Dalam upaya memberikan keuntungan ekonomis yang lebih tinggi kepada petani, maka lahan pertanian organik perlu dikembangkan dalam bentuk kawasan sehingga lebih terkonsentrasi dan lebih mudah di dalam pengelolaan. Permentan No 50/2012 tentang Pedoman Pengembangan Kawasan Pertanian memberikan aturan yang jelas tentang kriteria pengembangan suatu kawasan pertanian. Misalnya, dinyatakan bahwa kriteria khusus kawasan tanaman pangan dalam aspek luas agregat kawasan untuk masing-masing komoditas unggulan tanaman pangan adalah: padi, jagung, dan ubi kayu minimal 5.000 hektar; kedelai minimal 2.000 hektar; kacang tanah minimal 1.000 hektar; serta kacang hijau dan ubi jalar minimal 500 hektar. Untuk memperoleh luasan yang dimaksud, maka diperlukan penggabungan antar beberapa gabungan kelompok tani (gapoktan). Penggabungan lahan gapoktan yang dimungkinkan adalah lahan yang menghasilkan komoditas bersertifikat organik. Guna meringankan biaya sertifikasi, maka perlu dikembangkan sistem pertanian korporasi sesuai dengan Permentan No 18/2018 tentang Pedoman Pengembangan Kawasan Pertanian Berbasis Korporasi Petani.

Tabel 14. Luas Lahan Petani Organik di Bali

\begin{tabular}{cccc}
\hline Nomor & Kategori & $\begin{array}{c}\text { Jumlah Responden } \\
\text { (Kelompok) }\end{array}$ & Persentase (\%) \\
1 & $<15 \mathrm{Ha}$ & 72 & 90 \\
2 & $>16 \mathrm{Ha}-30 \mathrm{Ha}$ & 4 & 5 \\
3 & $>30 \mathrm{Ha}-50 \mathrm{Ha}$ & 4 & 5 \\
\hline
\end{tabular}

Pelaksanaan sistem pertanian organik memerlukan sumberdaya lahan yang sudah ditransformasi (go organic) dan sumberdaya manusia yang sudah berpengalaman dalam melakukan GAP. Langkah transformasi budidaya ke 
organik diperlukan minimal 2 tahun untuk tanaman semusim dan minimal 3 tahun untuk tanaman tahunan. Kedua prasyarat tersebut relatif terpenuhi oleh pelaku usahatani yang sudah pernah dan masih memiliki sertifikat Prima 3. Sejumlah 11 komoditas pertanian diketahui telah pernah mendapatkan sertifikat prima 3 dan sampai dengan saat ini masih menerapkan GAP walaupun beberapa masih menggunakan pestisida. Selain itu, pelaku usahatani yang pernah mendapatkan sertifikat Lesos tetapi sudah tidak berlaku lagi, juga masih menerapkan sistem budidaya organik secara konsisten. Para pelaku usahatani tersebut berpotensi untuk diarahkan untuk tetap melakukan pola budidaya organik dan diupayakan melalui pendekatan komunal untuk memperoleh sertifikat organik. Dengan memperhitung jumlah aktual produksi komoditas yang dihasilkan oleh pelaku usahatani tersebut (Tabel 15), maka apabila dikembangkan menjadi pelaku usahatani organik bersertifikat, maka terdapat penambahan kapasitas produksi komoditas organik. Jumlah potensial produksi komoditas dengan adanya kelompok tambahan tersebut disajikan dalam Tabel 16. Urutan komoditas organik yang potensial diproduksi dalam jumlah terbesar adalah melon, bawang merah, salak, manggis dan jahe.

Tabel 15. Data Kalender Produksi Komoditas Aman Pestisida (Bersertifikat Prima 3) di Provinsi Bali

\begin{tabular}{|c|c|c|c|c|c|c|c|c|c|c|c|}
\hline \multirow{2}{*}{ Komoditi } & \multicolumn{7}{|c|}{ Bulan } & \multirow{2}{*}{ Produsen } & \multirow{2}{*}{ Lokasi } & \multirow{2}{*}{ Produksi } & \multirow{2}{*}{ Luas Tanam } \\
\hline & $\operatorname{Jan}$ & \begin{tabular}{|l|l|l|} 
Peb & Mar & Apr \\
\end{tabular} & Mei Juni & \begin{tabular}{l|l|l|l|} 
nil & Ags \\
\end{tabular} & Sept $\mid$ Okt $\mid$ & Novi 1 & Des & & & & \\
\hline \multirow{2}{*}{ Anggur } & & & & & & & & Sumber Sari & Desa Kalianget, Serinit & 8 ton/40are & 40 are \\
\hline & & & & & & & & Amerta Nadi & Desa Banjar, Kecamatan Banjar & $15-20$ ton/ha & $1,5 \mathrm{ha}$ \\
\hline Bawang merah & & & & & & & & Kelompok tani karya Buahan & Desa buahan, kecamatan kintamani & 10 ton & 30 are \\
\hline Buah Bidara & & & & & & & & I Made Budiasa & Desa Banjar, Kecamatan Banjar & 3-4 Kuintal/ha/musim & 1,1 ha \\
\hline Cabai & & & & & & & & Karya Tani Lestari & Desa Selishaan Kecamatan Klungkung & $250 \mathrm{~kg} / \mathrm{musim}$ tanam & 50 are \\
\hline \multirow{4}{*}{ Jeruk } & & & & & & & & Sarining Amerta & Desa Telaga, Busungbiu & $800-1000 \mathrm{~kg} / 50$ are & 50 are \\
\hline & & & & & & & & Mertha Buana & Desa Katung Kecamatan Kintamani & 5 ton/70 are/sekali panen & 70 are \\
\hline & & & & & & & & Jeruk Lestari & Desa Bayung Gede, Kecamatan Kintamani & $12 \mathrm{Ton} / \mathrm{Ha}$ & $1,5 \mathrm{ha}$ \\
\hline & & & & & & & & Kelompok tani tegal sari & Desa awan Kecamatan kintamani & 6 Ton/ 60 are & 60 are \\
\hline \multirow{3}{*}{ Mangga } & & & & & & & & Baluk Mandiri & Desa Kaliasem, Kecamatan Banjar & 10 ton $/$ ha/th & 50 ha \\
\hline & & & & & & & & Usadha Karya & Desa Depehe, Kubutambahan & 1,8 ton/ 15 are & 15 are \\
\hline & & & & & & & & Arum manis & Desa Baturinggit Kecamatan Kubu & 50 ton/ 50 ha & $50 \mathrm{ha}$ \\
\hline Melon & & & & & & & & Pusat pertanian kreativ matahari terbit & Desa Sanur Denpasar Selatan & 205 ton/ha & 1 ha \\
\hline Paprika & & & & & & & & Mitra Praja Wredhi & Desa Pancasari, Sukasada & $3600 \mathrm{~kg} / 1200$ pohon & 10 are \\
\hline Pepaya & & & & & & & & UD. Karya Tani & Desa Dencarik, Kecamatan Banjar & 28 ton/ha & 1 ha \\
\hline Sayur & & & & & & & & Kelompok tunas makmur & Desa Baturiti Kecamatan Baturiti & $300-4500 \mathrm{~kg}$ & 10 are \\
\hline Strawberry & & & & & & & & Candi amerta sari & Desa Candikuning Kecamatan Baturiti & 8 ton/ tahun & 40 are \\
\hline
\end{tabular}

Peningkatan luasan lahan pertanian organik dengan mengandalkan lahan yang sudah memperoleh perlakuan GAP dapat diupayakan melalui 
beberapa mekanisme. Bantuan sertifikasi produk dapat diberikan bagi petani yang konsisten melaksanakan budidaya organik dan mengembangkan komoditas yang bernilai ekonomi tinggi terutama untuk tujuan ekspor.

Tabel 16. Potensi Produksi Komoditas Organik di Provinsi Bali

\begin{tabular}{|c|c|c|c|c|c|c|c|c|c|c|c|c|c|c|c|c|c|c|}
\hline \multirow[b]{2}{*}{ KABUPATEN } & \multicolumn{18}{|c|}{ Produksi (Ton/ Tahun) } \\
\hline & $\begin{array}{l}\text { Bawang } \\
\text { Merah }\end{array}$ & $\begin{array}{l}\text { Buah } \\
\text { Naga }\end{array}$ & Jahe & Manggis & Padi & $\begin{array}{c}\text { Pisang } \\
\text { Hijau }\end{array}$ & Salak & Sayuran & $\begin{array}{c}\text { Tanaman } \\
\text { Hias }\end{array}$ & Anggur & Bidara & Cabai & Jeruk & Mangga & Melon & Paprika & Pepaya & Strawberry \\
\hline Denpasar & & & & & & & & & & & & & & & 205 & & & \\
\hline Badung & & 12 & & & 1,5 & & & 0,6 & & & & & & & & & & \\
\hline Gianyar & & & 37,5 & & & & & & 5 & & & & & & & & & \\
\hline Bangli & 62 & & & & & & & & & & & & 23 & & & & & \\
\hline Klungkung & & & & & & & & & & & & 0,5 & & & & & & \\
\hline Buleleng & & & & & 2,2 & 33,6 & & 6 & & 28 & 0,4 & & & 11,8 & & 3,6 & 28 & \\
\hline Karangasem & & & & & & & 39,62 & & & & & & & 50 & & & & \\
\hline Jembrana & & & & 39 & & & & & & & & & & & & & & \\
\hline Tabanan & & & & & & & & 38,4 & & & & & & & & & & 8 \\
\hline $\begin{array}{l}\text { Total Produksi } \\
\text { (Ton/ Tahun) }\end{array}$ & 62 & 12 & 37,5 & 39 & 3,7 & 33,6 & 39,62 & 45 & 5 & 28 & 0,4 & 0,5 & 23 & 61,8 & 205 & 3,6 & 28 & 8 \\
\hline
\end{tabular}

Bantuan ini dapat diberikan kepada petani yang membudidayakan buah naga di Buleleng (Pak Kantra) yang menargetkan ekspor ke Negara Cina. Bantuan serupa dapat diberikan kepada petani coklat di Kabupaten Jembrana yang sudah beberapa kali berhasil mengekspor coklat ke Jepang dan Eropa serta petani mangga di Desa Baturinggit, Karangasem. Bantuan lain dalam bentuk pengadaan air irigasi dapat diupayakan untuk pelaku usahatani lahan kering di dataran tinggi atau didaerah Kabupaten Buleleng dan Karangasem terutama untuk produsen kacang mente yang sudah memiliki dokumen ICS. Kelompok tani lainnya memerlukan tambahan suplai pupuk organik, misalnya petani di Kabupaten Tabanan, Badung, dan Gianyar karena tidak cukupnya lumbung pupuk.

\section{Sistem Informasi Pertanian Organik Provinsi Bali}

Inovasi yang dihasilkan dari penelitian ini adalah sistem database pertanian organik Provinsi Bali yang online, terintegrasi, kompak, ringan, dan mudah dioperasikan. Sebagian data hasil penelitian digunakan di dalam penyusunan sistem informasi pertanian organik Provinsi Bali. Sistem informasi disusun dalam format Geoportal yang memuat fitur peta dasar dan menggunakan Query database. Fitur yang digunakan sangat responsif karena diupayakan untuk bisa dibuka dengan telepon genggam yang tergolong 
smartphone. Untuk itu, diperlukan server yang memuat layanan Geoportal ini dan peta cetak hasil penelitian ini ditampilkan dalam Geoportal.

Sistem informasi ini dapat dibuka pada laman berikut: http://80.211.45.108/gistanikbali/ atau http://80.211.163.231/gistanikbali/. Apabila laman tersebut diakses, pada bagian beranda akan terdapat tampilan berikut sebagai pembuka. Pada bagian kiri atas tercantum Pertanian Organik Provinsi Bali dan di bagian paling kanan ditampilkan konten web yang dibagi atas 3 bagian yaitu about (beranda), peneliti, dan map (peta). Pada bagian beranda ditampilkan sejumlah foto peneliti, kegiatan lapangan, foto produk yang dipasarkan dalam bentuk running photoes. (Gambar 9).

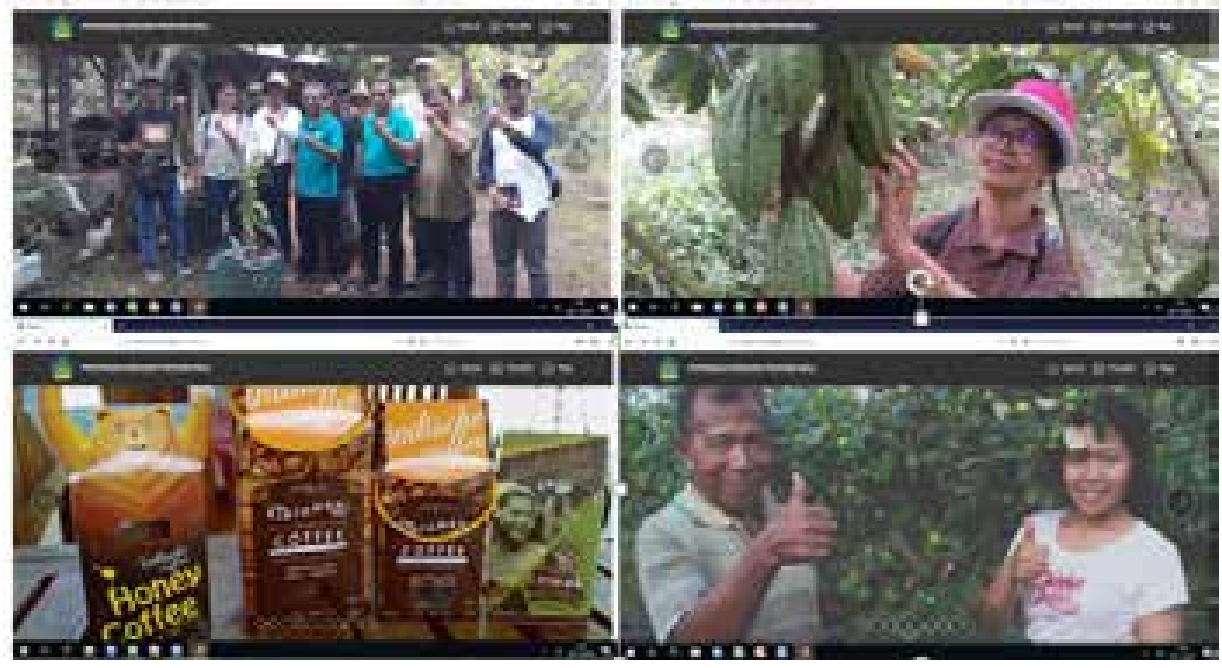

Gambar 9. Beberapa Tampilan Gambar dalam Beranda Sistem Informasi Pertanian Organik Provinsi Bali

Pada saat bagian Map diakses maka akan tampak tampilan berikut. Apabila ingin melihat tampilan peta secara utuh, maka kursor diarahkan ke bagian beranda yang berwarna biru dengan tulisan lihat peta (Gambar 10). Tulisan tersebut diklik untuk memunculkan peta utuh. Dalam peta pulau Bali tersebut akan tampil marker berwarna hijau (mengindikasikan usahatani organik bersertifikat dan sertifikat masih berlaku), kuning (mengindikasikan usahatani organik bersertifikat tetapi masa berlaku sertifikat sudah habis) dan coklat (mengindikasikan usahatani organik tidak bersertifikat). 


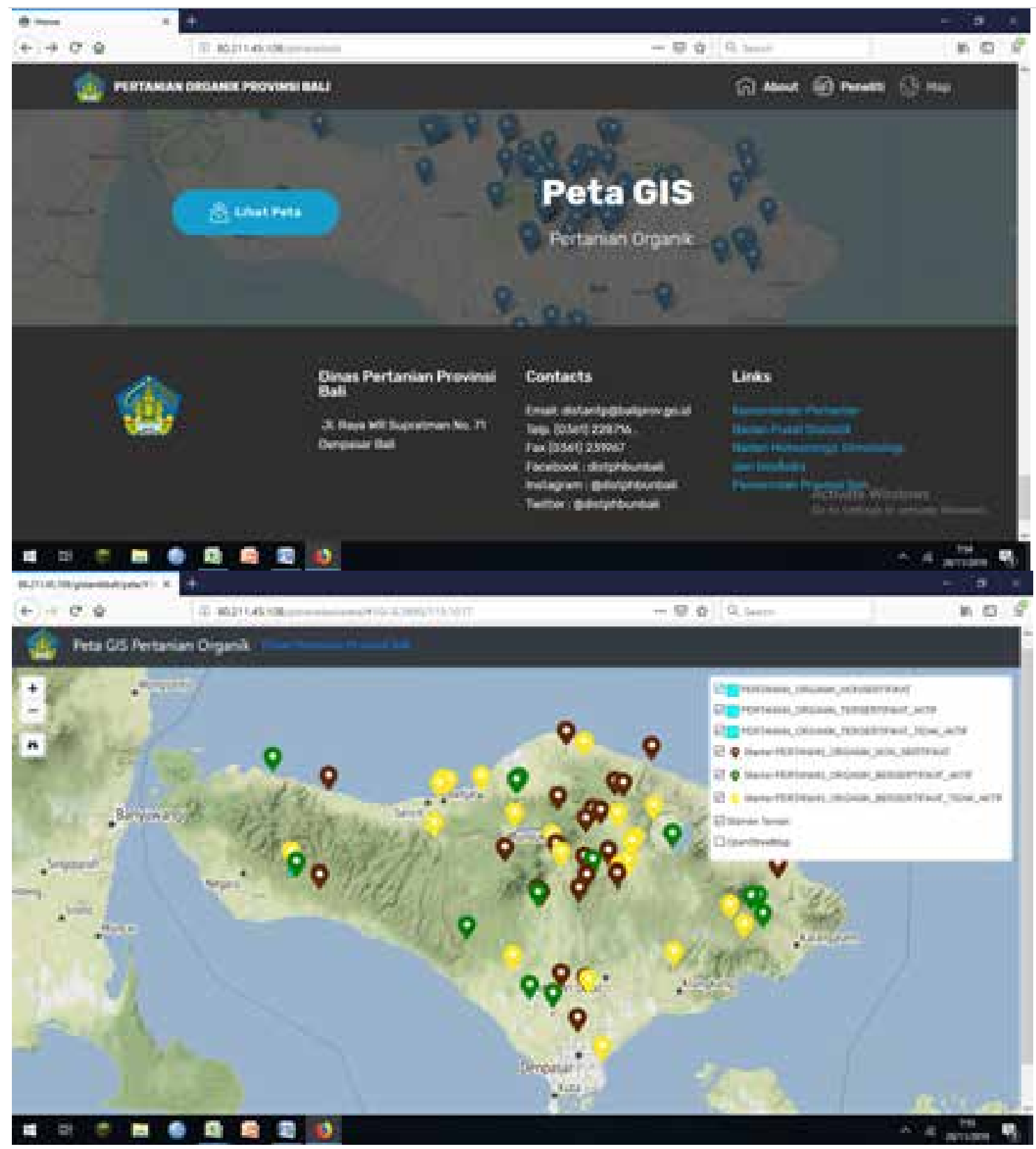

Gambar 10. Tampilan Fitur Peta

Pada saat diperlukan informasi mengenai usahatani atau komoditas yang dihasilkan, maka arahkan kurson ke salah satu marker balon dilajutkan dengan pembesaran 4 - 16 kali. Kemudian klik bagian dasar berwarna biru di kaki marker balon sehingga data base usahatani di titik tersebut akan ditampilkan dalam bentuk tabel data. Data yang dapat diakses adalah : nomer ID, nama produsen, lokasi usahatani, nama kabupaten, titik oordinat, luas lahan, produksi, produktivitas, nama sertifikat organik, status keaktivan sertifikat organik, dan jadwal produksi/panen raya (Gambar 11). 


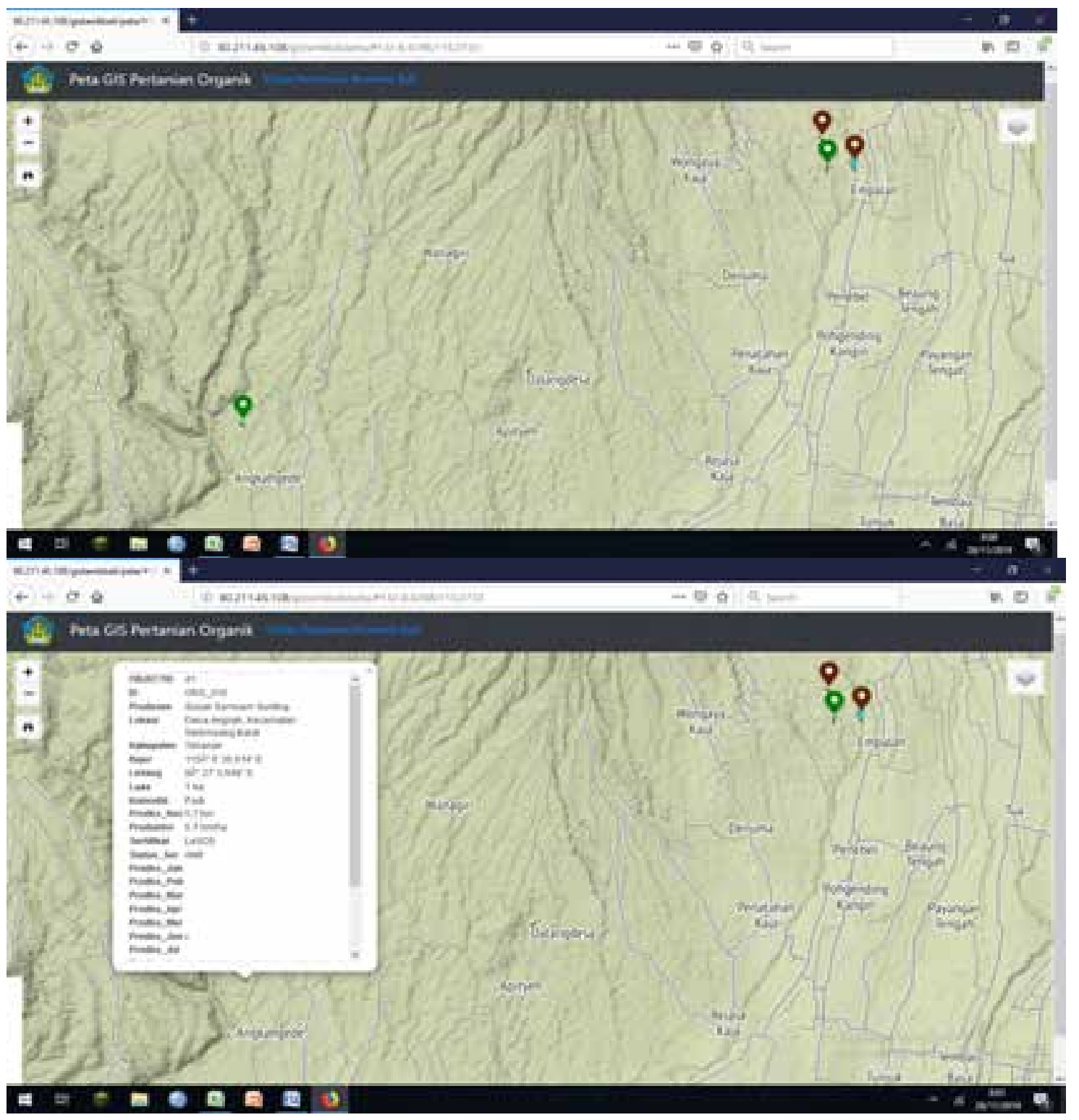

Gambar 11. Contoh Tampilan Detail Data Produsen, Lokasi, Luas Lahan, Produk, Jumlah Produk, dan Waktu Produksi

Hasil penelitian ini merupakan data penting sistem pertanian organik di wilayah Provinsi Bali yang belum pernah tercatat secara detail sebelumnya. Oleh karena itu, sistem informasi ini perlu selalu diperbaharui sehingga data yang ditampilkan selalu data yang terkini sesuai dengan kebutuhan stakeholder. Pembaharuan data diperlukan karena kegiatan usahatani sangat dinamis mengikuti kondisi agroekosistem, ketersediaan saprotan, dan kebutuhan pasar. Bagian terpenting dari pembaharuan data yang harus dilakukan adalah data produsen, produksi, dan waktu panen komoditas 
pertanian sehingga pembeli atau pihak eksternal dari produsen dapat dengan mudah untuk menemukan komoditas yang diperlukan diseluruh wilayah Provinsi Bali dan Pemerintah Provinsi Bali selalu dapat mengevaluasi faktor penyebab terjadinya fluktuasi produksi pada tingkat usahatani. Untuk itu, peranan para penyuluh pertanian perlu diperkuat dengan keterlibatan kelompok tani, gapoktan, subak dan Desa Adat setempat dalam mengawal keberlanjutan usahatani organik potensial di wilayah masing-masing.

Luasan areal pertanian organik yang terangkum dalam sistem informasi ini sangat rendah tetapi potensi pengembangan terbuka luas dengan langkah utama dengan mengembangkan sistem tersebut pada lahan yang menghasilkan komoditas yang masih atau pernah bersertifikat Prima. Untuk menjamin keberhasilan langkah tersebut maka diperlukan sumber daya manusia dan teknologi yang memadai, ketersediaan pasar, ketersediaan air irigasi bebas cemaran kimia atau teknologi bioremidiasinya, dan kemudahan registrasi lahan dan sertifikasi produk. Sumberdaya manusia yang potensial untuk dibina adalah petani yang sudah melaksanakan GAP dan para penyuluh pertanian. Kedua kelompok tersebut perlu mendapatkan pembinaan dan pengarahan lebih detail sehingga dapat lebih mengoptimalkan pelaksanaan sistem pertanian organik dengan memberdayakan sumber saprotan setempat. Potensi sumberdaya saprotan yang sudah tergarap cukup baik adalah kotoran ternak sapi yang diolah menjadi pupuk dan sudah dikomersialkan. Pengolahan tersebut telah dilakukan di Tabanan, Buleleng, dan Kelungkung. Sebagian besar produksi kotoran ternak sapi terutama di kabupaten lainnya belum dimanfaatkan secara maksimal sehingga potensi ini dapat diberdayakan dengan mengadopsi sistem pengelolaan dan produksi yang sudah dilakukan oleh produsen kompos di Tabanan, Klungkung, dan Buleleng. Untuk melengkapi keamanan produk kompos tersebut bagi sertifikasi produk pertanian organik, maka kompos tersebut juga perlu dievaluasi kualitasnya. Khusus untuk daerah lahan kering di dataran tinggi seperti Jembrana, bantuan ternak kambing sangat diperlukan untuk menunjang kebutuhan pupuk bagi lahan pertanian organik. Pengadaan ternak kambing ini merupakan skala prioritas karena kabupaten Jembrana satu-satunya produsen coklat yang telah 
berhasil mengekspor coklat organik ke luar negeri, seperti Amerika, Eropa dan Jepang. Produksi coklat yang diekspor masih terbatas karena terkendala produksi pada musim kemarau akibat keterbatasan air irigasi.

Penyediaan air irigasi yang bebas cemaran kimia perlu dibantu oleh Pemerintah Daerah Bali karena proses bioremidiasi sulit dilakukan oleh petani di lahan sawahnya. Penyediaan kolam-kolam pengolahan air memerlukan biaya dan ketersediaan lahan dalam jumlah tertentu yang tidak terjangkau oleh petani kecil.

Pengembangan sistem pertanian organik perlu dilakukan secara terarah dan jelas payung hukumnya. Peraturan Daerah Provinsi Bali Nomer 18 Tahun 2019 tentang Sistem Pertanian Organik telah disahkan untuk merespon pentingnya payung hukum untuk menguatkan pengembangan system pertanian organik di Bali. Dalam skala teknis, pewujudan pertanian organik di Bali perlu diawali dengan penyusunan Masterplan Pertanian Organik Provinsi Bali Tahun 20212027.

\section{SIMPULAN}

Berdasarkan pelaksanaan survei lapang diketahui bahwa kondisi kekinian pertanian organik adalah sebagai berikut. Dari sejumlah 106 responden pelaku usahatani, terdapat 25 pelaku usahatani organik (penerima sertifkat Lesos), tetapi hanya 9 pelaku usahatani yang memiliki sertifikat produk organik (7 bersertifikat Lesos dan 2 Bersertifikat Control Union) yang masih berlaku. Produsen komoditas pertanian organik terbanyak adalah di Kabupaten Buleleng, Tabanan, dan Bangli. Dua pelaku masing-masing berlokasi 2 Buleleng dan Badung, sedangkan 3 pelaku lainnya berlokasi di Kabupaten Tabanan. Komoditas organik yang dihasilkan adalah bawang merah, buah naga, jahe, manggis, padi, pisang hijau Taiwan, salak, sayuran, dan tanaman hias. Sebanyak 16 pelaku usaha tani yang memperoleh sertifikat Prima 3 tetapi hanya 1 kelompok tani yang masih berlaku. Komoditas yang pernah bersertifikat Prima 3 adalah anggur, bawang merah, buah bidara, cabai, jeruk, mangga, melon, paprika, pepaya, sayur dan strawberi. Profil usahatani organik 
di Bali tergolong cukup berkembang yang didukung oleh sistem produksi mandiri dan berkelanjutan serta sebagian telah bermitra.

Pengembangan sistem pertanian organik potensial dilakukan hampir diseluruh wilayah Provinsi Bali kecuali di Kota Denpasar dan Kabupaten Klungkung. Pengembangan secara jangka pendek dimungkinkan dengan beberapa keberadaan produsen, saprodi, pengolahan dan pemasaran produk, dan sinergitas dengan jasa agrowisata serta peningkatan status pelaku usahatani organik yang pernah memiliki sertifikat prima 3 dan Lesos. Beberapa kendala penting dalam melanjutkan sistem budidaya pertanian organik adalah status saprodi yang tidak bersertifikat, lahan belum teregistrasi, dan sulitnya untuk memperoleh sertifikat produk organik. Saat ini komoditas organik yang potensial diproduksi dalam jumlah terbesar adalah bawang merah, salak, manggis dan jahe.

Inovasi yang dihasilkan dari penelitian ini adalah sistem database pertanian organik Provinsi Bali yang online, terintegrasi, kompak, ringan, dan mudah dioperasikan. Sistem informasi ini dapat dibuka pada laman berikut: http://80.211.45.108/gistanikbali/ atau http://80.211.163.231/gistanikbali/.

Sejumlah saran berhasil dihimpun dari analisis hasil kajian ini serta pendapat yang mengemuka dari peserta FGD. Saran-saran tersebut adalah SEBAGI BERIKUT. Implementasi hasil kajian ini perlu dilakukan di seluruh wilayah Provinsi Bali untuk mengembangkan potensi sistem pertanian organik. Namun, oleh karena luasan lahan dan jumlah pelaku usahatani organik tergolong sangat kecil dibandingkan lahan pertanian dan jumlah pelaku usahatani konvensional, maka perlu dirancang Master Plan Kawasan Pertanian Organik Provinsi Bali Tahun 2021 - 2027 dengan menata kawasan untuk sistem pertanian organik dan sistem pertanian konvensional.

Hasil kajian ini perlu disosialisasikan. Di samping itu, langkah-langkah yang diperlukan dalam rangka pelaksanaan sistem pertanian organik adalah penyiapan SDM dalam implementasi dimulai dari PPL dan POPT, perancangan model sistem pertanian organik, kegiatan edukasi sejak dini mengenai pentingnya pertanian organik, penyediaan air atau teknologi prosesing air irigasi bebas cemaran bahan kimia, penyediaan teknologi hidroponik organik, 
perbaikan mutu komoditas pertanian, penyediaan pasar dan penghargaan untuk pelaku, penyediaan media khusus untuk petani organik, dan pemangkasan biaya sertifikasi dengan pembentukan LSO lokal di Bali.

\section{UCAPAN TERIMA KASIH}

Penelitian ini merupakan kerjasama antara Pemerintah Daerah Provinsi Bali melalui Badan Perencanaan Pembangunan Daerah, Penelitian dan Pengembangan Provinsi Bali dengan Universitas Udayana melalui Lembaga Penelitian dan Pengabdian Kepada Masyarakat dengan kontrak kerja Nomor: 027/720/PBJ/Litbang.BappedaLitbang dan 1132/UN14.4.A/KS/2019. Kami menyampaikan terima kasih atas fasilitasi dan mediasi yang telah diberikan oleh kedua lembaga tersebut sehingga penelitian ini dapat dilaksanakan dengan baik. Terima kasih juga kami sampaikan atas kerjasama para surveyor dalam menyelesaikan segala pekerjaan dengan penuh dedikasi.

\section{REFERENSI}

Arsana, I Nyoman; I Putu Sudiartawan; Ni Luh Gede Sudaryati; I Made Agus Gelgel Wirasuta; Pande Made Nova Armita; Ni Kadek Warditiani; Ni Made Widi Astuti; I Wayan Martadi Santika; Ida Bagus Wiryanatha; Putu Lakustini Cahyaningrum; Ida Bagus Putra Suta. 2020. Pengobatan Tradisional Bali Usadha Tiwang. Jurnal Bali Membangun Bali, Volume 1, Nomor 2, Agustus 2020. Dikutip dari: http://ejournal.baliprov.go.id/index.php/jbmb/article/view/112

BPS Propinsi Bali 2017-2018. Hasil Survei Pertanian Antar Sensus (SUTAS) 2018 Propinsi Bali. https://bali.bps.go.id. Diakses pada tanggal 30 Maret 2019.

BPS Propinsi Bali. 2019. Bali Dalam Angka.

Departemen pertanian. 2012. Peraturan Mentri Pertanian No. 50 Tahun 2012. Tentang Pedoman Pengembangan Kawasan Pertanian. Jakarta.

Juniartini, Ni Luh Putu. 2020. Pengelolaan Sampah Dari Lingkup Terkecil dan Pemberdayaan Masyarakat sebagai Bentuk Tindakan Peduli 
Lingkungan. Jurnal Bali Membangun Bali, Volume 1, Nomor 1, April 2020. Dikutip dari” http://ejournal.baliprov.go.id/index.php/jbmb/article/view/106.

Sulaeman, Dede, 2006, Perkembangan Pertanian Organik di Indonesia, http://agribisnis.deptan.go.id. Diunduh pada tanggal 25 Maret 2019.

Peraturan Menteri Pertanian Nomor 64/Permentan/OT.140/5/2013 tentang Sistem Pertanian Organik. Sekretaris Negara. Jakarta.

Peraturan Menteri Pertanian Nomor 18/Permentan/RC.040/4/2018 tentang Pedoman Pengembangan Kawasan Pertanian Berbasis Korporasi Petani.

Permatananda, Pande Ayu Naya Kasih; Anak Agung Sri Agung Aryastuti; Putu Nita Cahyawati; Desak Putu Citra Udiyani; D. Wijaya; I Gde Suranaya Pandit; Anak Agung Ngurah Mayun Wirajaya. 2020. Phytochemical and Antioxidant Capacity Test on Turmeric Extract (Curcuma Longa) Traditionally Processed in Bali. Jurnal Bali Membangun Bali, Volume 1, Nomor 2, Agustus 2020. Dikutip dari: http://ejournal.baliprov.go.id/index.php/jbmb/article/view/115 